\title{
An Intrinsic Neural Oscillator in the Degenerating Mouse Retina
}

\author{
Joanna Borowska, Stuart Trenholm, and Gautam B. Awatramani \\ Departments of Anatomy and Neurobiology, Neuroscience Institute, Dalhousie University, Halifax, Nova Scotia B3H 1X5, Canada
}

The loss of photoreceptors during retinal degeneration (RD) is known to lead to an increase in basal activity in remnant neural networks. To identify the source of activity, we combined two-photon imaging with patch-clamp techniques to examine the physiological properties of morphologically identified retinal neurons in a mouse model of RD $(r d 1)$. Analysis of activity in $r d 1$ ganglion cells revealed sustained oscillatory $(\sim 10 \mathrm{~Hz})$ synaptic activity in $\sim 30 \%$ of all classes of cells. Oscillatory activity persisted after putative inputs from residual photoreceptor, rod bipolar cell, and inhibitory amacrine cell synapses were pharmacologically blocked, suggesting that presynaptic cone bipolar cells were intrinsically active. Examination of presynaptic $r d 1 \mathrm{ON}$ and OFF bipolar cells indicated that they rested at relatively negative potentials (less than $-50 \mathrm{mV}$ ). However, in approximately half the cone bipolar cells, low-amplitude membrane oscillation $(\sim 5$ $\mathrm{mV}, \sim 10 \mathrm{~Hz}$ ) were apparent. Such oscillations were also observed in AII amacrine cells. Oscillations in ON cone bipolar and AII amacrine cells exhibited a weak apparent voltage dependence and were resistant to blockade of synaptic receptors, suggesting that, as in wild-type retina, they form an electrically coupled network. In addition, oscillations were insensitive to blockers of voltage-gated $\mathrm{Ca}^{2+}$ channels $\left(0.5 \mathrm{~mm} \mathrm{Cd}^{2+}\right.$ and $\left.0.5 \mathrm{~mm} \mathrm{Ni}^{2+}\right)$, ruling out known mechanisms that underlie oscillatory behavior in bipolar cells. Together, these results indicate that an electrically coupled network of ON cone bipolar/AII amacrine cells constitutes an intrinsic oscillator in the $r d 1$ retina that is likely to drive synaptic activity in downstream circuits.

\section{Introduction}

Recent methods, including cell transplantation (Tropepe et al., 2000; MacLaren et al., 2006), gene therapy (Acland et al., 2001), and electronic (Weiland et al., 2005) or biological (Bi et al., 2006; Lagali et al., 2008; Lin et al., 2008; Busskamp et al., 2010) implants, have demonstrated a remarkable potential for sight restoration during retinal degenerations (RD) associated with a loss of photoreceptors. Because all these strategies aim to stimulate remnant retinal circuits in the degenerate retina, it has become imperative to understand how neural circuits remodel in response to photoreceptor death (Marc et al., 2007).

Studies in the $r d 1$ mouse model for RD demonstrate that the loss of photoreceptors is accompanied by a marked increase in spontaneous spike activity in output in ganglion cells (Ye and Goo, 2007; Margolis et al., 2008; Stasheff, 2008). Such retinal activity may underlie stimulus-independent visual photopsias, commonly experienced by patients with RD (for review, see Margolis and Detwiler, 2010). Sustained activity would also be expected to degrade visual images generated by any retinal prostheses that use the remnant circuitry. A large effort now focuses on determining the source and cellular mechanisms that

Received Nov. 4, 2010; revised Jan. 24, 2011; accepted Feb. 1, 2011.

This work was supported by the Foundation for Fighting Blindness (Canada) and Canadian Institutes of Health Research Grant 100065 (G.B.A.). We thank Dr. W. Baldridge, Dr. F. Tremblay, and Dr. S. Barnes for useful discussions and for their helpful comments on this manuscript, Dr. L. Perez de Sevilla Müller for assistance in identifying ganglion cells, and Priyanka Singh and Belinda Dunn for providing technical support.

Correspondence should be addressed to Dr. Gautam B. Awatramani, Departments of Anatomy and Neurobiology, Neuroscience Institute, Dalhousie University, Halifax, Nova Scotia B3H 1X5, Canada. E-mail: gba@dal.ca.

DOI:10.1523/JNEUROSCI.5800-10.2011

Copyright $\odot 2011$ the authors $\quad 0270-6474 / 11 / 315000-13 \$ 15.00 / 0$ drive hyperactivity in ganglion cells in the degenerate retina (Borowska et al., 2010; Margolis and Detwiler, 2010; Stasheff and Andrews, 2010; Vaithianathan and Sagdullaev, 2010; Zeck and Menzler, 2010).

A recent study by Margolis et al. (2008) demonstrated that increased levels of excitatory and inhibitory synaptic inputs underlie hyperactivity in $r d 1$ ganglion cells. However, the source and cellular mechanisms driving the presynaptic circuitry remain unclear. One possibility is that changes occur at the level of bipolar cells. It has been suggested that the dysregulation of the signinverting metabotropic glutamate receptor 6 (mGluR6) signaling pathway (Strettoi and Pignatelli, 2000) could lead to tonic depolarization of ON bipolar cells, because these receptors usually serve to keep these cells hyperpolarized in healthy retinas. Isolated bipolar cells have also been shown to exhibit a sustained 5-10 Hz membrane oscillation when depolarized, which is mediated by L-type voltage-gated $\mathrm{Ca}^{2+}$ channels and $\mathrm{Ca}^{2+}$ dependent $\mathrm{K}^{+}$channels (Burrone and Lagnado, 1997). Because these resonance frequencies are similar to those of ganglion cell activity (Margolis et al., 2008; Stasheff, 2008), it suggests that such mechanisms could drive activity during RD. Alternately, excitation could be driven indirectly through intrinsically active inhibitory amacrine cells. Indeed a variety of amacrine cell types demonstrate intrinsic oscillatory potentials (Solessio et al., 2002; Vigh et al., 2003; Petit-Jacques et al., 2005). In this scheme, oscillations in particular inhibitory amacrine cells would modulate transmitter release at bipolar cell axon terminals via the activation of presynaptic GABA/glycine ionotropic receptors and trigger sustained spike activity in downstream ganglion cells (Margolis and Detwiler, 2010; Vaithianathan and Sagdullaev, 2010). 
To identify the sources of network activity in the $r d 1$ mouse retina, we combined whole-cell patch-clamp and two-photon imaging techniques to examine the properties of a variety of identified remnant neurons. We provide evidence for a novel form of intrinsic oscillatory activity that occurs within the presynaptic network of electrically coupled cells, including ON cone bipolar and AII amacrine cells, making these a likely source for excitatory drive in the $r d 1$ retina.

Parts of this work have been published previously (Borowska et al., 2010).

\section{Materials and Methods}

We used the $r d 1$ mouse model for RD carrying a mutation of the rod cGMP phosphodiesterase $\beta$ subunit (C3H/HeNCr1) and wild-type (wt) $(\mathrm{C} 57 \mathrm{BL} / 6 \mathrm{~J})$ mice in the majority of the experiments, which were obtained from Charles River Laboratories. A few control experiments were performed in a mouse line in which the $r d 1$ mutation was on a wt background (B6.C3-Pde6b ${ }^{r d 1}$ Hps4le/J; The Jackson Laboratory). Both male and female mice were used in this study. All mice were maintained on a $12 \mathrm{~h}$ light/dark cycle.

Retinal preparation. All procedures were performed in accordance with the Canadian Council on Animal Care and approved by Dalhousie University's Animal Care Committee. Briefly, mice were anesthetized and decapitated. The eyes were removed and placed in Ringer's solution. The cornea, lens, and iris were carefully cut away, and the retina was removed from the eyecup. The isolated retina was then placed down on a $0.22 \mu \mathrm{m}$ membrane filter (Millipore) with a precut window that enabled transmitted light to reach the retina and for the preparation to be viewed under infrared illumination with the aid of a Spot RT3 CCD camera (Diagnostic Instruments) attached to an upright Olympus BX51 WI fluorescent microscope, equipped with a $60 \times$ water-immersion lens (Olympus Canada). The preparation was continually bathed with control Ringer's solution containing the following (in $\mathrm{mm}$ ): $110 \mathrm{NaCl}, 2.5 \mathrm{KCl}, 1 \mathrm{CaCl}_{2}, 1.6$ $\mathrm{MgCl}_{2}, 10$ dextrose, and $22 \mathrm{NaHCO}_{3}, \mathrm{pH} 7.4$, bubbled with carbogen $(95 \%$ $\left.\mathrm{O}_{2} / 5 \% \mathrm{CO}_{2}\right)$. All experiments were performed near physiological temperatures $\left(36-37^{\circ} \mathrm{C}\right) .(1,2,5,6$-Tetrahydropyridin-4-yl)met hylphosphinic acid (TPMPA) and L-2-amino-4-phosphonobutyric acid (L-AP-4) were obtained from Tocris Bioscience. 2,3-Dioxo-6-nitro-1,2,3,4-tetrahydr obenzo[f] quinoxaline-7-sulfonamide (NBQX disodium salt) and D-(-)-2-amino-5phosphonopentanoic acid (AP-5) were from Ascent Scientific. All other chemicals were obtained from Sigma-Aldrich unless specified otherwise.

Whole-cell patch-clamp recordings. Voltage-clamp whole-cell recordings were made using 5-10 $\mathrm{M} \Omega$ electrodes containing the following (in mM): $112.5 \mathrm{CsCH}_{3} \mathrm{SO}_{3}, 9.7 \mathrm{KCl}, 1 \mathrm{MgCl}_{2}, 1.5$ EGTA, 10 HEPES, 4 ATP $\mathrm{Mg}_{2}, 0.5 \mathrm{GTP} \mathrm{Na}_{3}$, and 7.75 Neurobiotin (Vector Laboratories). The $\mathrm{pH}$ was adjusted to 7.4 with $\mathrm{KOH}$. For current-clamp experiments, electrodes contained the following (in $\mathrm{mM}$ ): $115 \mathrm{~K}^{+}$gluconate, $5 \mathrm{KCl}, 1$ $\mathrm{MgCl}_{2}, 10$ EGTA, 10 HEPES, 4 ATP $\mathrm{Mg}_{2}, 0.5 \mathrm{GTP} \mathrm{Na}_{3}$, and 7.75 Neurobiotin (and/or 1\% Lucifer yellow). The reversal potential for chloride $\left(E_{\mathrm{Cl}}\right)$ was calculated to be approximately $-70 \mathrm{mV}$. The voltage- and current-clamp recordings were made with a Multiclamp 700B amplifier (Molecular Devices). Analog signals were filtered at $1 \mathrm{kHz}$ and sampled at $2 \mathrm{kHz}$ with the Digitadata 1400 analog-to-digital board (Molecular Devices). pClamp10 (Molecular Devices) was used to control the voltage command outputs and acquire data. Junction potentials that were calculated to be 14 and $11 \mathrm{mV}$ for $\mathrm{K}^{+}$- and $\mathrm{Cs}^{+}$-based solutions, respectively, were corrected offline. For estimation of the resting potential of bipolar cells, only recordings with seal resistances greater than $2 \mathrm{G} \Omega$ were selected. The series resistance $\left(R_{\mathrm{s}}\right)$ was monitored throughout the experiments. For ganglion cell recordings, the average $R_{\mathrm{s}}$ was $27.6 \pm 1.2 \mathrm{M} \Omega$ (range, $13-40 \mathrm{M} \Omega ; n=70$ ). Errors associated with $R_{\mathrm{s}}$ were not compensated. For bipolar cell recordings, the average $R_{\mathrm{s}}$ was significantly higher $(48.0 \pm 1.9 \mathrm{M} \Omega ; n=22)$. In current-clamp mode, the bridge was adjusted accordingly.

Light stimulation. Stimuli were generated with a digital light processing projector (refresh rate, $75 \mathrm{~Hz}$; Texas Instruments) controlled with custom software written by Dr. David Balya (Friedrich Meischer Institute, Basel, Switzerland). Neutral density filters were used to control the stimulus en- ergy. The intensity of stimuli used was $0.5 \times 10^{10}$ photons $\cdot \mathrm{s}^{-1} \cdot \mathrm{cm}^{-2}$ (sampled at $500 \mathrm{~nm}$ ) as measured with a calibrated spectrophotometer (USB2000; Ocean Optics). Images were focused on the photoreceptor layer using the condenser of the microscope. Either full-field or spot stimuli (400 $\mu \mathrm{m}$ diameter) were presented at positive contrast.

Image acquisition. Images were acquired using a custom-built twophoton imaging system (Awatramani et al., 2007). Two-photon fluorescence excitation was performed with a Mai Tai DeepSee titanium: sapphire laser (Spectra Physics), tuned to $850 \mathrm{~nm}$ to excite Alexa Fluor 594 , introduced into single cells with the patch pipette. Images were captured through an Olympus IR-LUMPlanFl water-immersion objective $(60 \times, 0.9$ numerical aperture) and detected by photomultiplier tubes (Hamamatsu) using custom software routines in IgorPro (Wavemetrics), with a pixel size of $\sim 0.2 \mu \mathrm{m}$. Alternatively, cells were loaded with Neurobiotin during the physiological recording, fixed in $4 \%$ paraformaldehyde, and then processed for confocal analysis.

Cell identification. Ganglion, amacrine, and bipolar cells were distinguished based on their characteristic morphologies (Wässle et al., 2009). Cells were identified as $\mathrm{ON}$, OFF, or ON-OFF based on the stratification patterns of their dendritic or axonal processes in the inner plexiform layer (IPL). Ganglion cell layer (GCL) and amacrine cell layer delineated the proximal (0\%) and distal (100\%) boundaries of the IPL, respectively. ON and OFF cells stratified in the proximal $(0-60 \%)$ and distal (40$100 \%$ ) parts of the IPL, respectively (Ghosh et al., 2004).

Analysis. Spontaneous activity was quantified using event detection routines of Clampfit 10.0. Frequency characteristic of spontaneous activity were estimated from a representative $10-30 \mathrm{~s}$ segment by constructing power spectrum graphs (binned at $1.22-0.48 \mathrm{~Hz}$ ). Peaks in the power spectrum were confirmed by visual inspection of oscillations in the raw data. ANOVA and the nonparametric Kruskal-Wallis and Mann-Whitney $U$ tests were used to determine statistical significances of amplitude and frequency of events between multiple cell groups. Paired $t$ test was used to assess the effects of drugs. Significance is indicated as ${ }^{\star} p<0.05$, ${ }^{* *} p<0.01,{ }^{* *} p<0.001$. Data in graphs represent mean \pm SEM.

\section{Results}

\section{Hyperactivity in ON and OFF pathways of the $r d 1$ retina}

In the $r d 1$ mouse retina, photoreceptors begin to degenerate at approximately postnatal day 8 (P8). Degeneration is characterized by the loss of rods, followed by the loss of cones. By P30-P40, the one or two rows of photoreceptor cell bodies that remain (Carter-Dawson et al., 1978; Lin et al., 2009) do not appear to maintain their sensitivity to light (Strettoi et al., 2002), although they remain functionally connected with bipolar cells (Busskamp et al., 2010). In response to this sensory deafferentation, a marked increase in the spontaneous firing rates of ganglion cells has been observed previously (Ye and Goo, 2007; Margolis et al., 2008; Stasheff, 2008). To determine whether such activity arises in specific retinal circuits, we first recorded spike activity from single ganglion cells (P30-P70) and subsequently characterized their morphologies.

In adult wt mouse retina, ganglion cells can be broadly classified based on their functional responses to steps of light as $\mathrm{ON}$, $\mathrm{OFF}$, or ON-OFF. The dendrites of $\mathrm{ON}$ and OFF ganglion cells stratify in the proximal $(0-60 \%)$ and distal $(60-100 \%)$ layers of the IPL, respectively, whereas those of ON-OFF cells stratify in both layers. Post hoc morphological analysis revealed that the dendritic stratification patterns of $r d 1$ ganglion cells were maintained at a stage when photoreceptors are almost completely lost (Margolis et al., 2008; Mazzoni et al., 2008), allowing for their classification using similar criteria as that for wt ganglion cells. Examples of Neurobiotin-filled ON, OFF, or ON-OFF ganglion cells in the $r d 1$ retina are illustrated in Figure $1 A$ (top). Spontaneous action potentials were observed in all three types of ganglion cells in the $r d 1$ retina (Fig. 1 Aii). Although the average spike rate varied from cell to cell, there was no difference in activity levels between the different classes of ganglion cells. Histograms 
of the average spike rate measured in individual ganglion cells of each class (Fig. 1 Aiii) illustrate this heterogeneity. The average firing rate was $5.5 \pm 1.4 \mathrm{~Hz}$ for ON cells $(n=20), 10.6 \pm 1.9 \mathrm{~Hz}$ for OFF cells $(n=25)$, and $7.1 \pm 2.0 \mathrm{~Hz}$ for ONOFF cells $(n=13)$, with no statistical significant difference between the three groups ( $p=0.12$, Kruskal-Wallis test). Such variability in ganglion cell activity is consistent with previous reports (Stasheff, 2008: median spike rate was $3-8 \mathrm{~Hz}$; range, $0-40 \mathrm{~Hz}$ for all types of cells in the ganglion cell layer; P28-P51) and suggest that circuits can exist in different states.

The temporal structure of spike activity in $r d 1$ ganglion cells also varied in a manner independent of cell type. Histograms of interspike intervals were either unimodal ( 34 of 53 cells) or bimodal in a subset of cells (19 of 53). Bimodal distributions were apparent in ganglion cells that exhibited pronounced oscillatory bursts of spike activity (Margolis et al., 2008) (Fig. 1C). Spectral analysis of spike activity in these cells revealed a clear peak in the power corresponding to the fundamental frequency of the oscillatory response $(12.6 \pm 1.7 \mathrm{~Hz} ; n=19)(16 \mathrm{~Hz} /$ $0.060 \mathrm{~ms}$ in the example illustrated in Fig. 1 Cii,Ciii), consistent with previous reports (Ye and Goo, 2007; Margolis et al., 2008; Stasheff, 2008). Such oscillatory components were observed in approximately one-third of all three classes of ganglion cells (OFF, 36\%; ON, 30\%; ONOFF, 31\%). Thus, spontaneous spiking activity in the $r d 1$ retina often has a strong oscillatory component (Margolis et al., 2008; Stasheff, 2008) that does not appear to be associated with specific types of ganglion cells.

To ascertain that ganglion cell hyperactivity was a consequence of photoreceptor cell death, we compared the levels of activity in ON-OFF ganglion cells in $r d 1$ and wt retina. $\mathrm{ON}-\mathrm{OFF}$ ganglion cells can be easily distinguished by their bistratified dendritic arborizations. Figure 1, $A$ and $B$, illustrates the characteristic morphology of ON-OFF ganglion cells in the $r d 1$ and wt retina. In contrast to cells in the $r d 1$ retina, wt $\mathrm{ON}-\mathrm{OFF}$ ganglion cells exhibited a low background spiking rate of $0.2 \pm 0.1 \mathrm{~Hz}(n=13)$, consistent with previous reports (Oesch et al., 2005; Chen et al., 2009). The background rate of firing in these bistratified cells was significantly lower in wt compared with $r d 1$ retina $(p<0.001)$. Low background rates of firing in the wt cells were not likely a result of a compromised preparation, because robust $\mathrm{ON}$ and $\mathrm{OFF}$ light-evoked responses $(\mathrm{ON}, 258 \pm 21 \mathrm{~Hz}$; OFF, $202 \pm 26 \mathrm{~Hz} ; n=13$ ) could be measured in response to step changes in contrast (Fig. $1 \mathrm{Bii}$ ). The comparison of activity between particular cell types in the $r d 1$ and wt, within the bistrati-
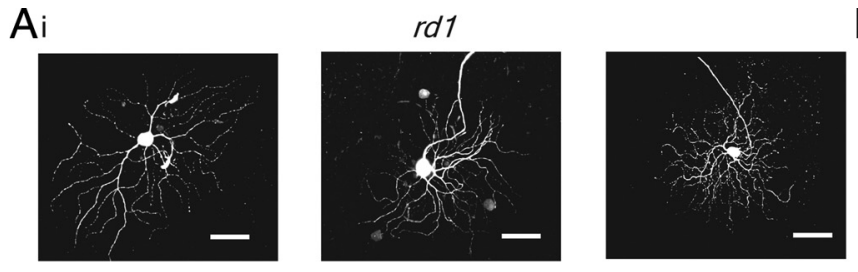

$\mathrm{Bi}$
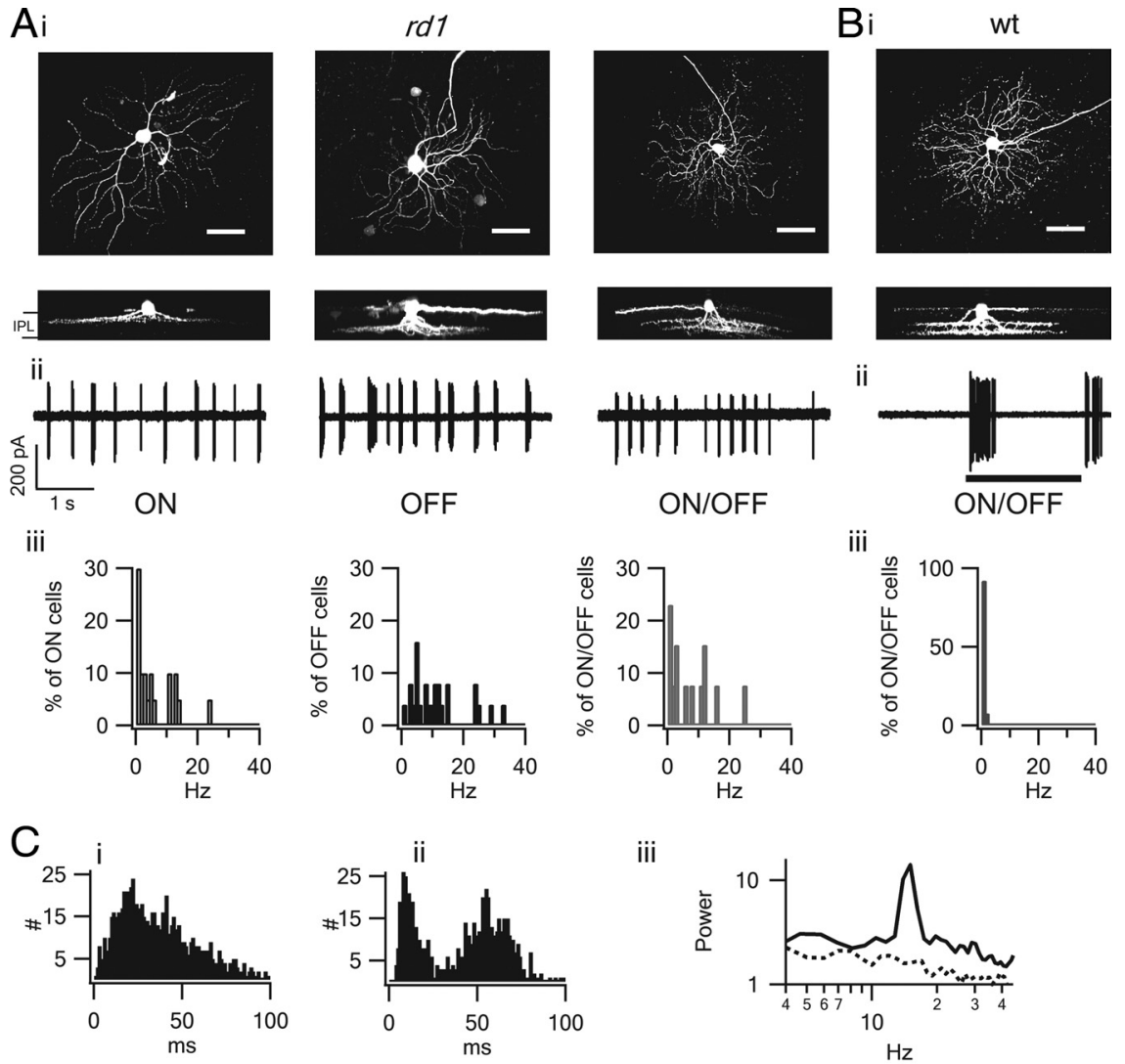

iii
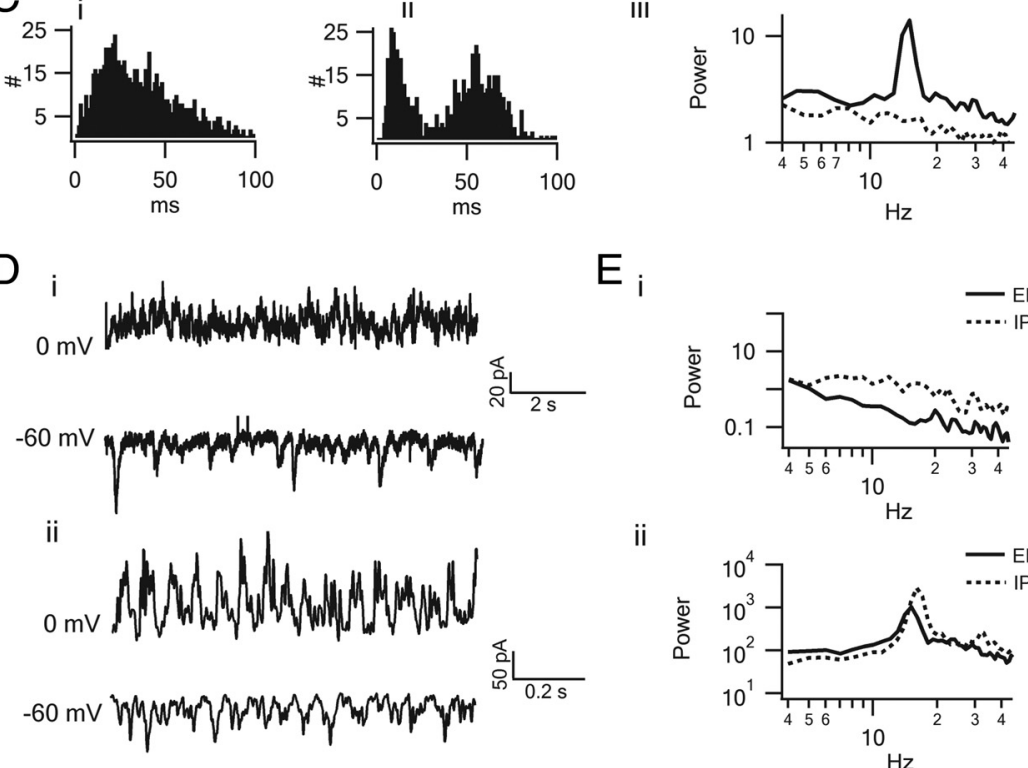

$E_{i}$

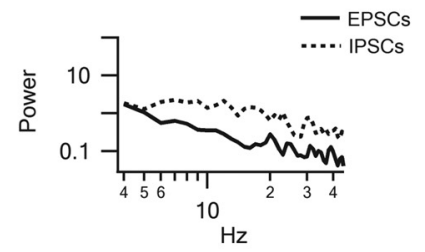

i

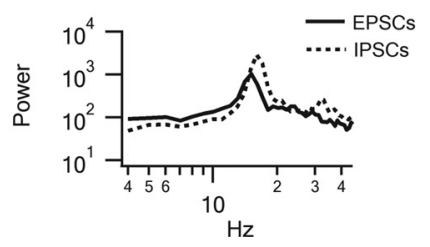

Figure 1. Spontaneous activity in morphologically identified ganglion cells. Ai, Confocal image stacks of ON (left), OFF (middle), and ON/OFF (right) $r d 1$ ganglion cells. Side views of these cells (bottom row) illustrate their dendritic stratification in the IPL. Scale bars, $50 \mu \mathrm{m}$. Aii, Spike activity recorded in the ganglion cells shown in Ai. Aiii, Histograms of the average spike rate of individual ON $(n=20)$, OFF $(n=25)$, and ON-OFF $(n=13)$ rd1 ganglion cells. B illustrates the morphology of a wt ON-OFF bistratified ganglion cell (i) and its light-evoked spike activity (horizontal black bar indicates the duration of the light stimulus). Biii, A histogram of the average rate of spontaneous spike activity from 13 wt $0 \mathrm{~N}-0 \mathrm{FF}$ ganglion cells is plotted. $\boldsymbol{C}$, Histograms of the interevent intervals from ganglion cells illustrating random (i) and rhythmic patterns (ii) of spike activity. The power spectra of spike activity for the same two cells are overlaid (iii). D, Examples of inhibitory and excitatory currents measured (under voltage clamp at 0 and $-60 \mathrm{mV}$, respectively) in two different ganglion cells (i, ii; note the different timescales). $\boldsymbol{E}$, Power spectra for sIPSCs and sEPSCs for two cells shown in $\boldsymbol{D}$.

fied class of ganglion cells in this study and the ON and OFF $\alpha$ ganglion cells in a previous study (Margolis et al., 2008), strongly support the notion that increased spontaneous spike rate is associated with RD.

Spontaneous synaptic inputs to $r d 1$ ganglion cells

To understand what factors contribute to varied levels of activity in ganglion cells, we evaluated the properties of their spontaneous (s) EPSCs and IPSCs, respectively (Fig. 1D). When ganglion cells were 
A

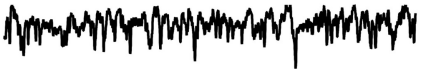

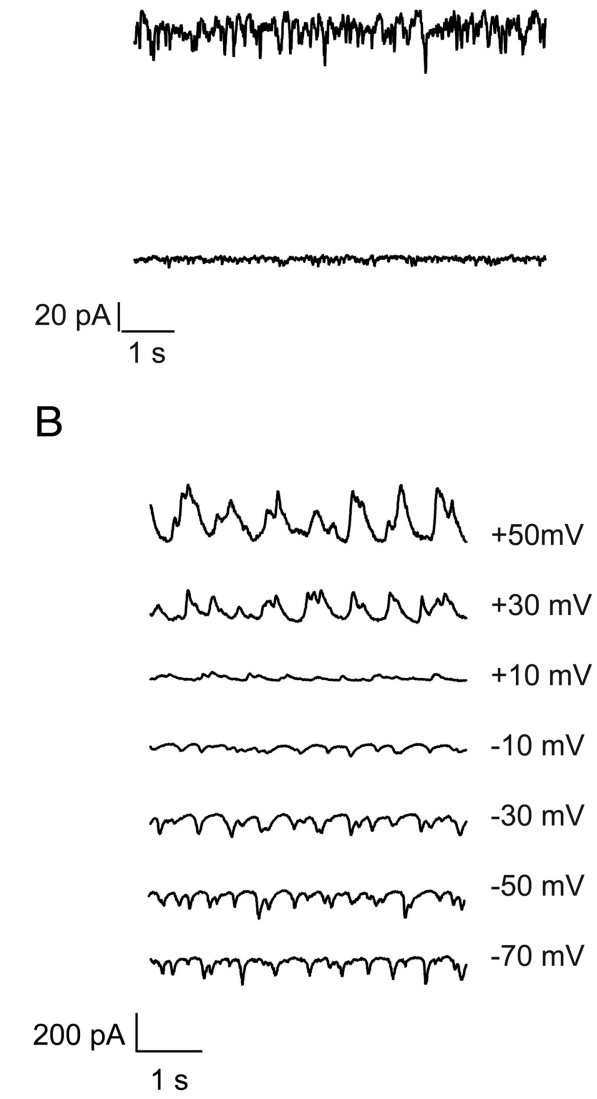

Inhibitory Blockers
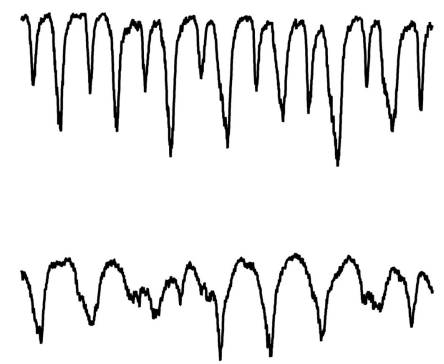

$\mathrm{C}_{\mathrm{i}}$

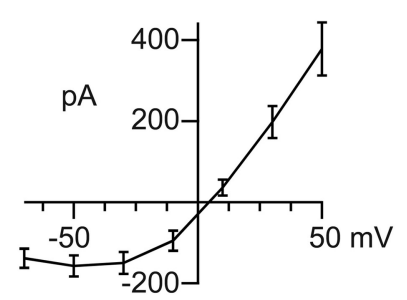

ii

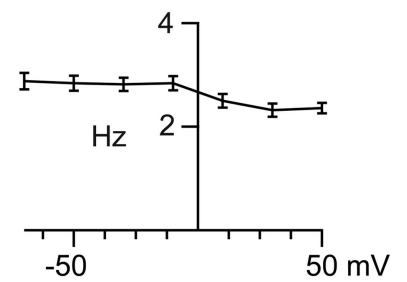

Figure 2. Spontaneous activity within excitatory circuits in the $r d 1$ retina in the absence of inhibitory inputs. $A$, Examples of SEPSCS $\left(V_{\text {HOLD }}\right.$ of $\left.-60 \mathrm{mV}\right)$ measured from two ganglion cells with differing levels of synaptic activity, before and after the bath application of inhibitory receptor antagonists (50 $\mu \mathrm{m}$ picrotoxin and $5 \mu \mathrm{m}$ strychnine). $\boldsymbol{B}$, Example traces depicting SEPSCS at different holding potentials (as indicated on the right of the traces). $C$, The average peak amplitude (i) and frequency (ii) of sEPSC as function of holding potential $(n=5)$.

voltage-clamped, high rates of sEPSCs (measured near $-60 \mathrm{mV}$, $\sim E_{\mathrm{Cl}-}$ ) and sIPSCs (measured near $0 \mathrm{mV}, \sim E_{\text {excitation }}$ ) were apparent, indicating that the presynaptic pathways were active. The average amplitude of the sEPSCs was $76 \pm 26 \mathrm{pA}$ and that for the sIPSCs was $91 \pm 14 \mathrm{pA}(n=41 ; 9 \mathrm{ON}, 19 \mathrm{OFF}$, and $13 \mathrm{ON}-\mathrm{OFF})$. The average frequency of sEPSCs was $12.7 \pm 1.2 \mathrm{~Hz}$ and was $12.4 \pm 1.1$ $\mathrm{Hz}$ for sIPSCs. Similar to spike activity, approximately one-third of the ganglion cells (15 of $41 ; 10 \mathrm{OFF}, 1 \mathrm{ON}$, and 4 ON-OFF cells) exhibited sEPSCs and sIPSCs that were oscillatory. Oscillatory currents gave rise to a distinct peak in the power spectrum (Fig. 1 Eii) (Margolis et al., 2008) and had similar frequencies (sEPSCs, $12.0 \pm$ $1.7 \mathrm{~Hz}$; sIPSCs, $13.5 \pm 2.2 \mathrm{~Hz}$ ) as noted for spike activity. We also observed similar rhythmic patterns of spontaneous activity in ganglion cells in a different strain of the $r d 1$ mice (on a C57BL/6 background; $9.3 \pm 1.8 \mathrm{~Hz} ; p=0.128$, Mann-Whitney $U$ test; data not shown), indicating that hyperactivity was not attributable to secondary mutations associated with the mouse $\mathrm{C} 3 \mathrm{H}$ strain used in this study (Hoelter et al., 2008). Thus, spontaneous activity in a variety of ganglion cell types appears to be associated with changes in activity of both inhibitory as well as excitatory presynaptic pathways.

\section{Blocking inhibitory receptors augments sEPSCs in $r d 1$ ganglion cells}

The heterogeneous levels of synaptic activity observed in $r d 1$ ganglion cells were present in single preparations, suggesting that these were not attributable to variability in experimental conditions. However, when we blocked inhibitory receptors with $50 \mu \mathrm{M}$ picrotoxin and $5 \mu \mathrm{M}$ strychnine, we observed a uniform pattern of activity in all ganglion cells. Regardless of the initial levels of activity in $r d 1$ ganglion cells in control conditions, when inhibitory receptor blockers were applied, spontaneous events appeared as low-frequency $(\sim 2-4 \mathrm{~Hz})$ synchronized oscillatory bursts. Figure $2 A$ illustrates two examples of ganglion cells with different levels of sEPSCs. In the more active cell, largeamplitude sEPSCs (average peak amplitude, $91 \pm 22 \mathrm{pA}$ ) were apparent, whereas the second cell was relatively quiet, with a few detectable events (average peak amplitude, $7 \pm 3 \mathrm{pA}$ ). In both cells, however, application of the inhibitory antagonists dramatically increased the amplitude of events, to $221 \pm 57$ and $160 \pm 38 \mathrm{pA}$, respectively. On average, inhibitory blockers decreased the frequency from $9.9 \pm 0.9$ to $3.7 \pm 0.4 \mathrm{~Hz}(n=26 ; p<$ 0.001 ) but increased the average peak amplitude of events from $28 \pm 3$ to $158 \pm 16$ pA $(p<0.001)$. Thus, inhibition appears to play a significant role in curtailing activity in the $r d 1$ retina.

To test whether inhibitory blockade resulted in changes of bipolar cell output rather than activity mediated through electrical coupling from neighboring amacrine and ganglion cells that were intrinsically active, we next tested the voltage dependence of ganglion cell sEPSCs. Figure $2 B$ illustrates examples of sEPSCs measured at different holding potentials (in the presence of inhibitory blockers). Plotting the average peak amplitude of events measured in five cells (one ON, three OFF, and one ON-OFF) against the holding potential revealed a nonlinear relationship characteristic of events mediated by a combination of AMPA/KA and NMDA receptors (Fig. 2C) (Diamond and Copenhagen, 1993; Sagdullaev et al., 2006; Manookin et al., 2010). Indeed, these events were largely suppressed by NBQX and AP-5 (89 \pm $6 \%$ block; $n=3$ ), which are selective antagonists for AMPA/ kainate (KA) and NMDA receptors, respectively. In addition, the frequency of sEPSCs was essentially independent of voltage (Fig. $2 C)$, consistent with the idea that these events arise presynaptically. Together, these findings suggest that spontaneous activity within excitatory circuits in the $r d 1$ retina can be generated without inhibitory input.

\section{Spontaneous synaptic output from cone bipolar cells measured in ganglion cells}

Under conditions of inhibitory receptor blockade, excitatory synaptic activity in $r d 1$ ganglion cells could be initiated at (1) residual photoreceptors (Busskamp et al., 2010), (2) rod ON bipolar cells, or (3) cone bipolar/AII amacrine cells (which are known to be electrically coupled in wt retina). To distinguish between these possible sources, we compared activity before and after the application of AMPA/KA antagonist (20 $\mu \mathrm{M}$ NBQX) and 

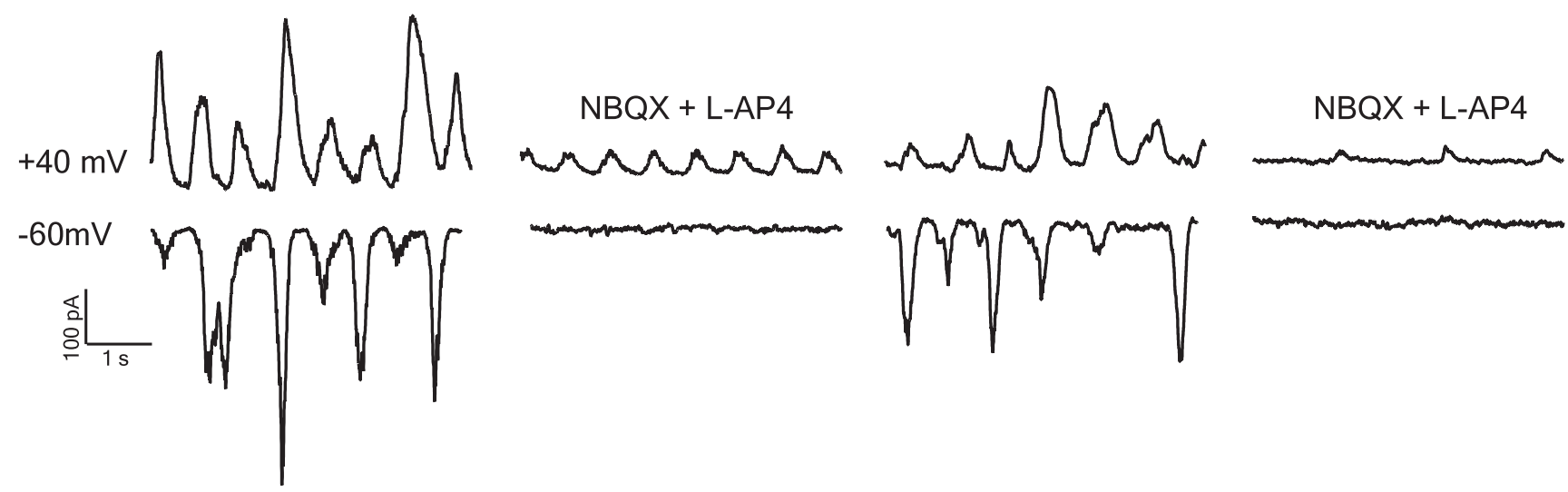

Figure 3. Spontaneous output of the $r d 1$ cone bipolar cells. $A$, Examples of sEPSCs measured at +40 and $-60 \mathrm{mV}$ in the presence of inhibitory receptor antagonists ( $50 \mu \mathrm{m}$ picrotoxin, $5 \mu \mathrm{m}$ strychnine, and $100 \mu \mathrm{m}$ TPMPA) before (left) and after photoreceptor/rod bipolar cells synapses were blocked by the addition of $20 \mu \mathrm{m} \mathrm{L}$-AP-4 and $5 \mu \mathrm{M}$ NBQX (right). $\boldsymbol{B}$, Activity in ganglion cells in wt retina under the same pharmacological conditions as in $\boldsymbol{A}$.

the mGluR6 agonist (20 $\mu \mathrm{M}$ L-AP-4). NBQX is known to block photoreceptor-to-OFF bipolar cell and rod ON bipolar-to-AII amacrine cell synapses, whereas L-AP-4 blocks glutamatergic transmission at the photoreceptor-to-ON bipolar cell synapses (Slaughter and Miller, 1981). L-AP-4 might also act on axonal terminals of bipolar cells (Awatramani and Slaughter, 2001) and amacrine cells (Quraishi et al., 2007); therefore, these data need to be interpreted with caution. To monitor activity in ganglion cells in the presence of NBQX, in these experiments, we took advantage of the selective expression of synaptic NMDA receptors in these cells (Diamond and Copenhagen, 1993; Sagdullaev et al., 2006; Manookin et al., 2010) and monitored output of bipolar cells as NMDA-receptor-mediated sEPSCs at a holding potential of $+40 \mathrm{mV}$ (in which these receptors would be relieved of their $\mathrm{Mg}^{2+}$ block) (Jahr and Stevens, 1990). Using this method, the intrinsic activity of the cone bipolar/AII amacrine cell network was assessed in relative isolation.

Figure $3 A$ illustrates an example of sEPSCs measured in an $r d 1$ ganglion cell at -60 and $+40 \mathrm{mV}$ in the presence of a mixture of inhibitory blockers ( $50 \mu \mathrm{M}$ picrotoxin, $5 \mu \mathrm{M}$ strychnine, and 100 $\mu \mathrm{M}$ TPMPA; note in the added presence of TPMPA in these experiments, sEPSCs tended to have a lower frequency, but qualitatively this mixture of antagonists had the same effects as picrotoxin and strychnine alone). Bath application of NBQX and L-AP-4 significantly reduced the average amplitude of sEPSCs measured at $-60 \mathrm{mV}$ by $85 \pm 4 \%$, consistent with the large contribution of AMPA receptors to the sEPSC at these potentials (Fig. 3A). However, at $+40 \mathrm{mV}$, sEPSCs were less sensitive to these excitatory blockers and on average were reduced by $60 \pm$ $8 \%(p<0.001)$. Interestingly, the frequency of these remaining NMDA-receptor-mediated sEPSCs was not significantly altered compared with control conditions $(1.6 \pm 0.2 \mathrm{~Hz}$ compared with $1.8 \pm 0.2 \mathrm{~Hz} ; p=0.11$; data combined from two ON, seven OFF, and four ON-OFF ganglion cells). These results suggest that, under conditions of inhibitory receptor blockade, the cone bipolar/AII amacrine cell networks are inherently active and form the principal source of glutamate that drives downstream ganglion cells.

Similar to $r d 1$ retina, large sEPCSs were also apparent in wt ganglion cells in the presence of inhibitory receptor antagonists (Fig. 3B). In wt ganglion cells, however, L-AP-4 and NBQX decreased both the peak amplitude (by $91 \pm 3 \%$ at $-60 \mathrm{mV}$ and
$80 \pm 6 \%$ at $+40 \mathrm{mV}$; data combined from five ON, two OFF, and one ON-OFF ganglion cells) and the frequency of sEPSCs measured at $+40 \mathrm{mV}$ (Fig. $3 B)(1.4 \pm 0.2$ to $0.9 \pm 0.2 \mathrm{~Hz} ; p<0.05)$. The decrease in frequency suggests that a significant part of the spontaneous activity arises from photoreceptors and/or rod $\mathrm{ON}$ bipolar cells. Importantly, the frequency of NMDA-receptormediated sEPSCs was significantly lower in wt versus $r d 1$ ganglion cells $(0.9 \pm 0.2 \mathrm{~Hz}$ in wt retina vs $1.6 \pm 0.2 \mathrm{~Hz}$ in $r d 1$ retina; $p<0.05)$. Thus, under pharmacological isolation, wt cone bipolar/AII amacrine cell networks are spontaneously active, although significantly less so compared with in the $r d 1$ retina.

An important point to be considered in the abovementioned pharmacological analysis is that, under the nonphysiological conditions of inhibitory receptor block, a different set of synaptic mechanisms may operate that may not be recruited under control conditions. Therefore, these experiments do not rule out the contribution of inhibitory networks to spontaneous activity but rather highlight a change in excitability of the presynaptic network of excitatory neurons in their ability to sustain oscillatory activity during RD.

\section{Spontaneous inhibitory activity primarily relies on synaptic activations of glutamate receptors}

To test whether inhibitory circuitry was intrinsically active, we examined the effects of blocking glutamate receptor signaling (using NBQX plus L-AP-4) (Fig. 4A,B) on sIPSCs measured in $r d 1$ ganglion cells. Excitatory blockers potently reduced the average peak amplitude of sIPSCs by $70 \pm 6 \%$ (91.9 \pm 17.6 to $26.1 \pm$ $5.8 \mathrm{pA} ; n=6$; three OFF, one ON, and two ON-OFF cells; $p<$ $0.05)$, suggesting that inhibition primarily relies on glutamate receptor activation. Excitatory blockers also reduced the sIPSC frequency from $14.8 \pm 1.9$ to $8.5 \pm 3.4 \mathrm{~Hz}(p<0.05)$. The residual inhibitory inputs suggest that a small but significant fraction of the inhibitory drive arises from intrinsically active amacrine cells (see Discussion).

We also recorded the membrane potential of the displaced amacrine cells in the ganglion cell layer of the $r d 1$ retina. Like ganglion cells, amacrine cells also exhibited spontaneous fluctuations in membrane potential (Fig. 4C,D). In amacrine cells, spontaneous activity was primarily reduced when glutamate receptor signaling was blocked. Excitatory blockers reduced the average frequency by $79 \pm 8 \%(n=5$; two narrow-field, two 
A

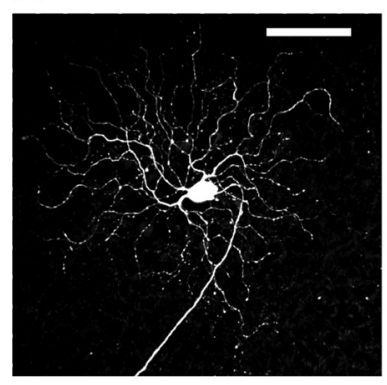

B

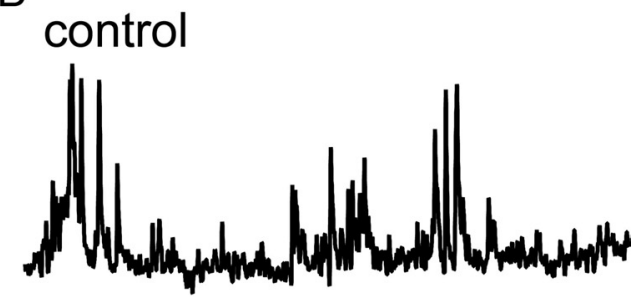

NBQX + L-AP4

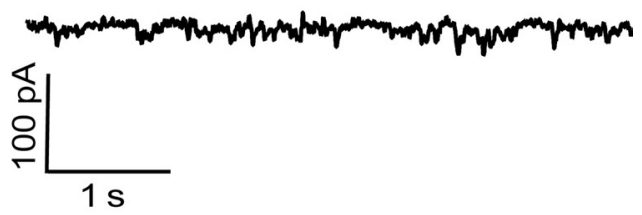

C

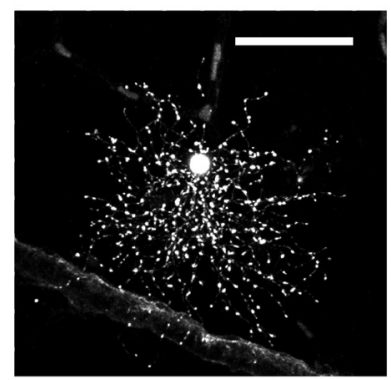

D control
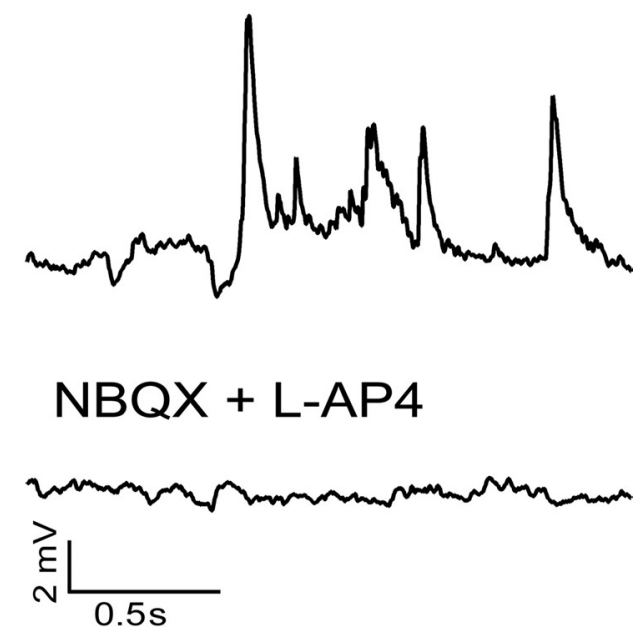

Figure 4. Amacrine cell activity primarily relies on activation of glutamate receptors. $A$, Example of a Neurobiotin-filled $r d 10 F F$ ganglion cell. $\boldsymbol{B}$, IPSCS recorded ( $V_{\text {HоLD }}$ of $0 \mathrm{mV}$ ) in the ganglion cell shown in $A$ in control Ringer's solution and in the presence of excitatory blockers (5 $\mu \mathrm{m} \mathrm{NBQX}$ and $20 \mu \mathrm{m} \mathrm{L}-A \mathrm{P}-4)$. C, Example of a Neurobiotin-filled $r d 1$ amacrine cell in the ganglion cell layer. D. The spontaneous postsynaptic potentials in the cell shown in $\boldsymbol{C}$, in control Ringer's solution and in the presence of excitatory blockers.

wide-field, and one bistratified amacrine cells; $p<0.01)$ and amplitude by $70 \pm 8 \%$ of control $(p<0.05)$. Hence, activity in inhibitory pathways in the $r d 1$ retina primarily relies on spontaneous excitatory inputs.

\section{rd1 bipolar cells appear morphologically intact and have} negative resting potentials

The experiments described so far implicate cone bipolar/AII amacrine cells as being a principal source of network activity in the $r d 1$ retina. Because glutamate usually keeps the ON bipolar cells hyperpolarized (via an action on the sign-inverting mGlur6 receptor), it might be expected that the loss of photoreceptor input during RD would depolarize these cells. To explore this possibility, we directly examined the resting properties of these cells, using whole-cell patch-clamp recordings in a whole-mount retinal preparation. Alexa Fluor 594 was included in the intracellular solution to permit live two-photon laser scanning imaging and assessment of the bipolar cell type (Fig. 5).
As in wt retina, bipolar cells could be classified as ON or OFF based on the level of their axonal stratification in the IPL (see Materials and Methods) (Wässle et al., 2009). Rod ON bipolar cells could be easily distinguished by their bulbous axon terminals in the most proximal layers of the IPL. Figure $5 A$ illustrates examples of OFF, ON, and rod ON bipolar cells in the $r d 1$ retina. As in wt retina, axonal terminals of $r d 1$ cone bipolar cells appear to ramify in precise strata of the IPL. Figure $5 B$ plots the axonal stratification depth in the IPL for 54 bipolar cells and illustrates the bias toward recording from ON bipolar cells (41 of 54 cells). However, the recordings did not appear to bias particular types of ON bipolar cell types because axon terminals were found to ramify throughout the IPL. Bipolar cell axons appeared to maintain their typical branched patterns with a number of telodendria sprouting off the main axon (Ghosh et al., 2004). Examples of the bipolar axonal arborizations for the different types of cells are illustrated in Figure $5 A$ (bottom). Thus, at the light microscopic level, bipolar terminals in the inner retina appear to maintain their structure during retinal degeneration (Lagali et al., 2008).

When bipolar cells membranes were polarized by a series a $50 \mathrm{~ms}$ pulses $(-120$ to $+40 \mathrm{mV}$ ) from a holding potential of $-60 \mathrm{mV}$ (Fig. 5C), inward rectifying $\mathrm{K}^{+}$ and $I_{\mathrm{H}}$ currents and delayed rectifying outward $\mathrm{K}^{+}$currents were observed, similar to those described previously in bipolar cells in the wt rodent retina $(\mathrm{Hu}$ and Pan, 2002; Ma et al., 2003). Because the complements of these currents vary between subtypes of bipolar cells (Müller et al., 2003; Ivanova and Müller, 2006), we did not perform a detailed comparison between wt and $r d 1$ bipolar cells. Instead, we focused on measuring the holding potential at which the current was zero, i.e., the resting potential (Fig. 5D). Interestingly, both $\mathrm{ON}$ and OFF bipolar cells had relatively negative resting membrane potentials $(\mathrm{ON},-52.5 \pm 1.3$ $\mathrm{mV}, n=12$; OFF, $-49.5 \pm 1.9 \mathrm{mV}, n=6$ ). Although recordings with high seal resistances were selected for these analysis (see Materials and Methods), current leak through the seal is still expected to lead to underestimations of the true resting potential. Hence, a tonic membrane depolarization of bipolar cells does not appear to underlie downstream activity in the $r d 1$ retina. Together, these results suggest that $r d 1$ bipolar cells maintain negative resting potentials and relatively normal axonal arborizations, even at a stage when their dendrites undergo an extensive remodeling in the outer retina in response to photoreceptor degeneration (Strettoi and Pignatelli, 2000).

\section{Spontaneous activity in $r d 1$ bipolar cells}

The most striking feature observed in $r d 1$ bipolar cell recordings was the occurrence of spontaneous membrane oscillations (Fig. 
$6 A)$. In 18 of $30 \mathrm{ON}$ cone bipolar cells and 5 of 13 OFF cone bipolar cells studied, spontaneous membrane oscillations $(1-11 \mathrm{mV})$ were observed. Similar to the rhythmic activity observed in $r d 1$ ganglion cells, bipolar cell membrane oscillations were extremely robust and persisted for the entire duration of the recording (up to $45 \mathrm{~min}$ ). Neither the frequency nor amplitude was correlated with the depth of the cone bipolar axonal projections in the IPL (Fig. 6D,E), indicating that activity occurred in most of the subtypes of cells. The rod ON bipolar cells were exceptions. Although they exhibited membrane fluctuations, oscillatory activity was never observed in these cells $(n=11)$. Spectral analysis of oscillatory activity in cone bipolar cells revealed a distinct peak corresponding to an oscillatory frequency of $11.8 \pm 0.9 \mathrm{~Hz}(n=23 ; 18 \mathrm{ON}$ and 5 OFF bipolar cells) (Fig. 6C). The average amplitude of these oscillations was $4 \pm 0.6$ $\mathrm{mV}$. If such oscillations arise in $\mathrm{ON}$ and OFF bipolar cell terminals, the somatic measurements likely underestimate both the true amplitude and kinetics of the rhythmic events. In contrast to $r d 1$ retina, oscillations were never observed in wt retina ( six ON bipolar cells and four OFF bipolar cells) (Fig. 6B). Thus, oscillatory activity appears to be associated with RD.

In bipolar cells that did not exhibit oscillatory activity, sporadic postsynaptic potentials (sPSPs) were often observed. These varied in amplitude $(1-10 \mathrm{mV} ; n=$ $12 \mathrm{ON}$ and $8 \mathrm{OFF}$ bipolar cells) (see Fig. $8 \mathrm{~A}$ ). Although the sPSPs measured in $r d 1$ bipolar cells were relatively small in amplitude $(2.2 \pm 0.5 \mathrm{mV})$ and low in frequency $(1.1 \pm 0.3 \mathrm{~Hz})$, if they triggered transmitter release, they could be effective in generating a large component of the non-oscillatory activity measured in ganglion cells, because these cell integrate inputs from a large number of bipolar cells.

\section{Rhythmic activity in $r d 1$ AII amacrine cells}

ON cone bipolar cells are known to be directly coupled to AII amacrine cells through gap junctions (Deans et al., 2002). Wholecell patch-clamp procedure applied in the whole-mount preparation resulted in a high background labeling when Neurobiotin was added to the intracellular solution and prevented a direct analysis of tracer coupling between these cell types. However, direct recordings from AII amacrine cells in the $r d 1$ retina also revealed a strong oscillatory component (Fig. 7A). Figure $7 C$ illustrates the typical morphology of an AII amacrine cell, as observed in the live $r d 1$ preparation. Spectral analysis of the membrane potential of $r d 1$ AII amacrine cells revealed a distinct peak corresponding to an oscillatory frequency of $12 \pm 0.6 \mathrm{~Hz}$ $(n=4)$ (Fig. 7D). In contrast, oscillations were not observed in wt AII amacrine cells $(n=4)$ (Fig. 7 B, D) (Manookin et al., 2008; Murphy and Rieke, 2008; Münch et al., 2009) (but see Veruki and Hartveit, 2002). Figure $7 B$ illustrates the relatively stable baseline of a wt AII amacrine cell. Only when presented with light stimuli are significant deviations observed. Figure $7 B$ (inset) illustrates
B
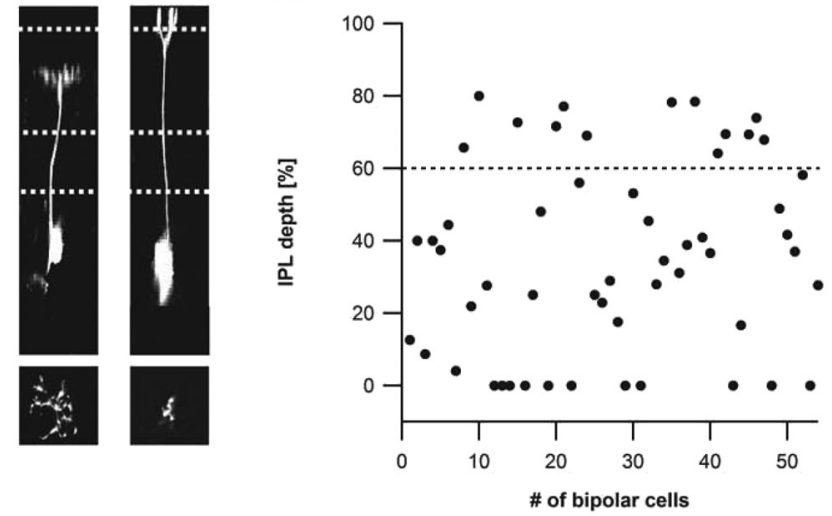

E
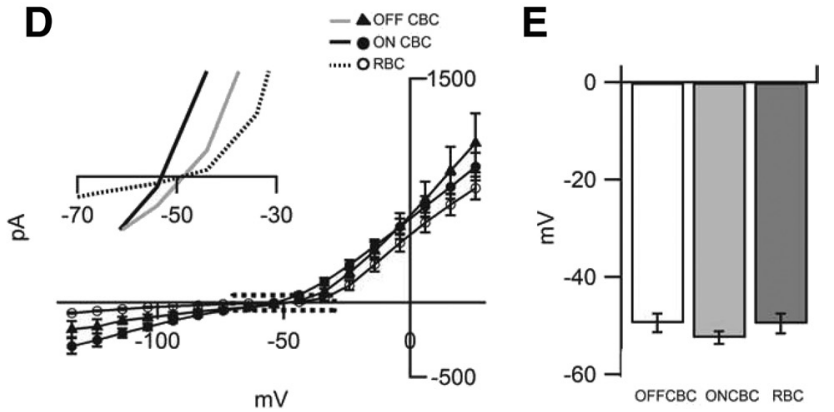

Figure 5. $0 \mathrm{~N}$ and $\mathrm{OFF} r d 1$ bipolar cells appear morphologically intact and have negative resting potentials. $\boldsymbol{A}$, Two-photon image stacks through different layers of the $r d 1$ retina after electrophysiological recording from bipolar cells reveals Alexa Fluor 594 of (left, top to bottom) the $\mathrm{GCL}$, the bipolar cell axon, the amacrine cell layer, and the bipolar cell soma. The thickness of the in $r d 1$ OFF, $0 \mathrm{~N}$, and rod bipolar cells. The boxed region is shown at a higher magnification to illustrate the average voltages where currents reverse (inset). $\boldsymbol{E}$, Plot of the average resting potentials in rd1 bipolar cells.

the spiking responses of an AII amacrine cell to a step change in contrast. Thus, the loss of photoreceptors appears to trigger changes that lead to oscillations in the membrane potential of AII amacrine cells. Moreover, oscillatory activity in $r d 1$ AII amacrine cells were of similar frequency to that observed in ON cone bipolar cells $(p>0.05)$, suggesting that they are electrically coupled to one another.

\section{Apparent voltage dependence of spontaneous oscillatory activity}

To understand the mechanisms underlying spontaneous activity in bipolar cells, we next evaluated their voltage dependence. Figure $8 \mathrm{~A}$ illustrates example traces of spontaneous PSPs measured at different potentials. These events were relatively small $(2.2 \pm$ $0.5 \mathrm{mV} ; n=20 ; 12 \mathrm{ON}$ cone bipolar cells, 8 OFF cone bipolar cells) and low in frequency $(1.1 \pm 0.3 \mathrm{~Hz})$. Spontaneous PSPs reversed near $-60 \mathrm{mV}\left(\sim E_{\mathrm{Cl}} ; n=4\right)$ (Fig. $\left.8 A, D\right)$, indicating that they were mediated by $\mathrm{Cl}^{-}$channels, probably those gated by GABA or glycine. This is consistent with the findings that these receptors may be upregulated at bipolar cell terminals in the rd retina (Varela et al., 2003).

In contrast, oscillatory activity in $r d 1$ bipolar cells exhibited a mild sensitivity to changes in somatic voltage. Neither the frequency nor the amplitude was strongly attenuated when currents were applied to modulate the potential at the soma $(-80$ to -20 
A

ON CBC

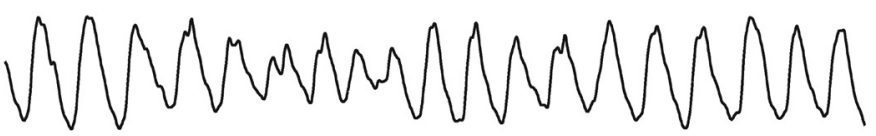

OFF CBC

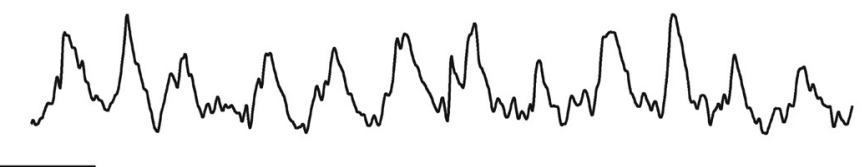

C

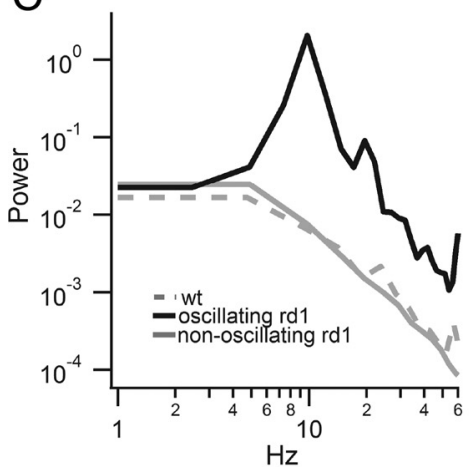

$r d 1$

D

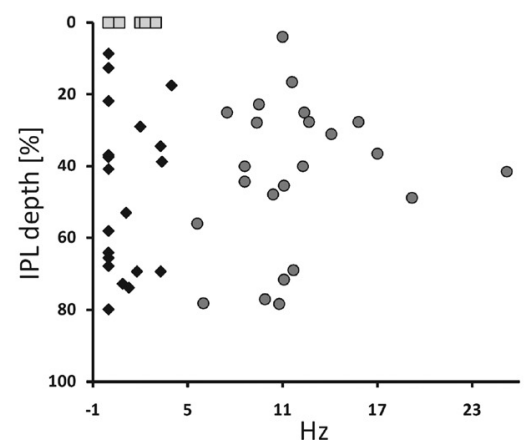

B

ON CBC

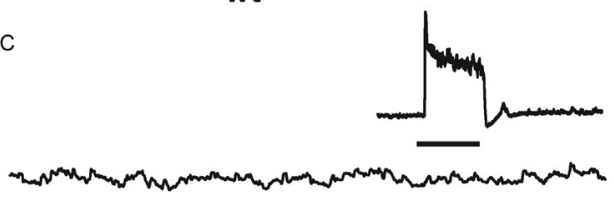

OFF CBC

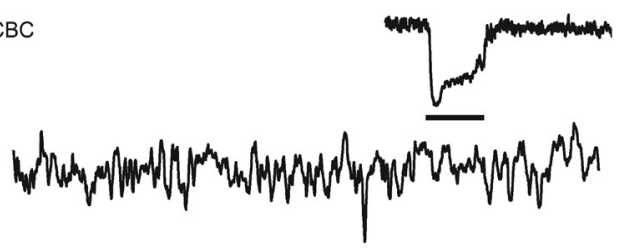

E

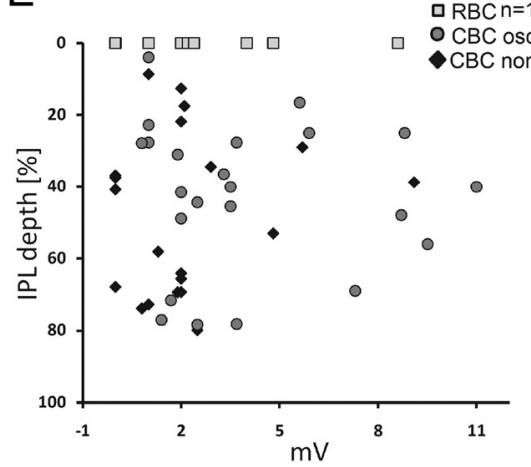

Figure 6. Spontaneous activity in $r d 1$ and wt bipolar cells. $A$, Representative traces depicting oscillatory membrane potential of $r d 10 \mathrm{ON}$ (top) and 0FF (bottom) cone bipolar cells (CBC), recorded in the whole-mount retina. $\boldsymbol{B}$, Oscillatory activity is absent in wt $\mathrm{ON}$ and $\mathrm{OFF}$ cone bipolar cells. The responses to spots of light are illustrated in the insets. Calibration: vertical bar, $2 \mathrm{mV}$ for all traces in $\boldsymbol{A}$ and $\boldsymbol{B}$ and $10 \mathrm{mV}$ for insets in $\boldsymbol{B}$; horizontal bar, $0.5 \mathrm{~s}$ for all traces in $\boldsymbol{A}$ and $\boldsymbol{B}$ and $3 \mathrm{~s}$ for insets in $\boldsymbol{B}$. C, Power spectra of the oscillating (black line), non-oscillating $r d 10 \mathrm{~N}$ cone bipolar cells (gray line) and a wt bipolar cell (gray dotted line). The average frequency $(\boldsymbol{D})$ and peak amplitude $(\boldsymbol{E})$ of events are plotted against the depth in the IPL at which bipolar axons terminate. 0 scillating $r d 1$ cone bipolar cells are represented as gray circles. Non-oscillating $r d 1$ cone bipolar cells are represented as black diamonds, and $r d 1$ rod bipolar cells (RBC) are represented as light gray squares.

$\mathrm{mV})$. Figure $8, B$ and $C$, illustrates the robust oscillatory potentials measured at three different membrane potentials, from an ON cone bipolar and AII amacrine cell, respectively. Oscillations persisted at the depolarized voltages (approximately $-20 \mathrm{mV}$ ). However, in contrast to bipolar cells, $\mathrm{Na}^{+}$channel activity caused AII amacrine cells to spike near threshold and augment the amplitude of oscillations (Fig. $8 C$ ). Figure $8 D$ compares the normalized average amplitude of oscillations in cone ON bipolar and AII amacrine cell at different holding potentials. The amplitude of ON cone bipolar cell and AII amacrine cell oscillations was reduced by $10-40 \%$ near $0 \mathrm{mV}$. A weak apparent voltage dependence is consistent with these cells being part of an electrically coupled network.

Membrane oscillations in ON bipolar and AII cells do not rely on chemical synaptic transmission or on voltage-gated $\mathrm{Ca}^{2+}$ channels

To test the role of chemical synaptic transmission in mediating spontaneous activity in bipolar and AII cells, we examined the effects of a mixture of inhibitory and/or excitatory synaptic blockers on such activity. Spontaneous PSPs (that reversed near $E_{\mathrm{Cl}-}$ ) measured in an $\mathrm{ON}$ bipolar cell were completely abolished in the presence of NBQX and L-AP-4 (Fig. 9A), consistent with our findings that most inhibitory amacrine cell activity relied on activation of glutamate receptors. Thus, active amacrine cells appear to drive feedforward inhibition to ganglion cells as well as feedback inhibition to bipolar cells. However, in all bipolar cells that exhibited oscillatory activity, bath application of these block- ers had relatively minor effects (Fig. 9D). Blocking chemical transmission did not affect the amplitude $(3.3 \pm 0.9 \mathrm{mV}$ compared with control, $5.6 \pm 2.2 \mathrm{mV} ; n=4 ; p>0.05)$ nor the frequency of oscillations $(8.6 \pm 1.2 \mathrm{~Hz}$ compared with control, $11.0 \pm 0.9 \mathrm{~Hz} ; p>0.05)$. Similarly, in three AII amacrine cells tested, neither the frequency $(13.6 \pm 1.9 \mathrm{~Hz}$ compared with control, $14.1 \pm 1.6 \mathrm{~Hz} ; p>0.05)$ nor the amplitude $(4.3 \pm 0.9 \mathrm{mV}$ compared with control, $3.3 \pm 0.5 \mathrm{mV} ; p>0.05)$ of oscillations appeared to be affected by blockade of chemical transmission. It is interesting to note that, under similar pharmacological conditions, ganglion cell sEPSCs occur at a lower frequency $(\sim 1-3$ $\mathrm{Hz}$ ), suggesting that the membrane oscillation of the bipolar cells is low-pass filtered when inhibition is compromised. Nevertheless, together, these data support the idea that that oscillatory activity arises from intrinsic properties within the network of bipolar/AII amacrine cells.

Previous studies demonstrated intrinsic $\mathrm{Ca}^{2+}$-dependent oscillations in bipolar cells, which were most pronounced when these cells were isolated and studied in acute cultured preparations (Burrone and Lagnado, 1997; Ma and Pan, 2003; Palmer, 2006). Could $\mathrm{Ca}^{2+}$ channel activity mediate such oscillations in $r d 1$ retina? To test the role of voltage-gated $\mathrm{Ca}^{2+}$ channels, we compared the effects of blocking voltage-gated $\mathrm{Ca}^{2+}$ channels, using a combination of $\mathrm{Cd}^{2+}$ and $\mathrm{Ni}^{2+}$, on bipolar/AII and ganglion cell activity. Figure 9 shows an example of oscillations recorded before and after the application of $\mathrm{Cd}^{2+} / \mathrm{Ni}^{2+}$. Even when used at relatively high concentrations $(200-500$ $\mu \mathrm{M})$, these inorganic channel blockers did not significantly 
affect the frequency $(11.8 \pm 1.7 \mathrm{~Hz}$ compared with $12.2 \pm 1.4 \mathrm{~Hz}$ observed in control; $n=5$; data combined from three ON bipolar and two AII amacrine cells; $p>$ $0.05)$ or the amplitude $(2.6 \pm 1.4 \mathrm{mV}$ compared with control, $3.0 \pm 2.0 \mathrm{mV} ; p>0.05$ ). In contrast, $\mathrm{Cd}^{2+} / \mathrm{Ni}^{2+}$ almost completely abolished synaptic responses measured in ganglion cells. (data not shown; $n=4$ ). Thus, voltage-gated $\mathrm{Ca}^{2+}$ channels activity does not appear to be important for driving membrane oscillations but is essential for translating them into transmitter release from bipolar cell terminals.

\section{Discussion}

Our results suggest that, when photoreceptors degenerate in $r d 1$ mouse retina, intrinsic activity within networks of cone bipolar and AII amacrine cells leads to a tonic rhythmic stimulation of ganglion cells. Low-amplitude membrane oscillations in these networks occur through a novel mechanism, which relies on neither chemical synaptic transmission nor voltage-gated $\mathrm{Ca}^{2+}$ channels. The implications for vision restoration strategies are discussed.

Increased ganglion cell activity in the $r d 1$ retina is driven by intrinsic activity in the cone bipolar/AII amacrine cell network

It has been recently postulated that oscillatory activity in the $r d 1$ retina arises in a subset of inhibitory amacrine cells (Vaithianathan and Sagdullaev, 2010; Margolis and Detwiler). Indeed, in wt retina, a subset of inhibitory amacrine cells have the biophysical characteristics that enable them to sustain periodic responses (Solessio et al., 2002; Vigh et al., 2003; PetitJacques et al., 2005). In this scheme, inhibitory amacrine cells modulate transmitter release at bipolar cell axon terminals via the activation of presynaptic GABA/glycine ionotropic receptors and trigger oscillatory spike activity in downstream ganglion cells (Vaithianathan and Sagdullaev, 2010; Margolis and Detwiler, 2010). However, our current results suggest the incorporation of a neural oscillator formed by ON cone bipolar and AII amacrine cells (Fig. 10). In this revised scheme, intrinsic oscillations in the AII/ cone ON bipolar cells provide the major drive to both amacrine and ganglion cells. In addition, extending the known AII amacrine cell circuit in wt retina (Manookin et al., 2008; Murphy and Rieke, 2008; Münch et al., 2009), we speculate that oscillations in the AII amacrine cells could carry over to the OFF system through gly-

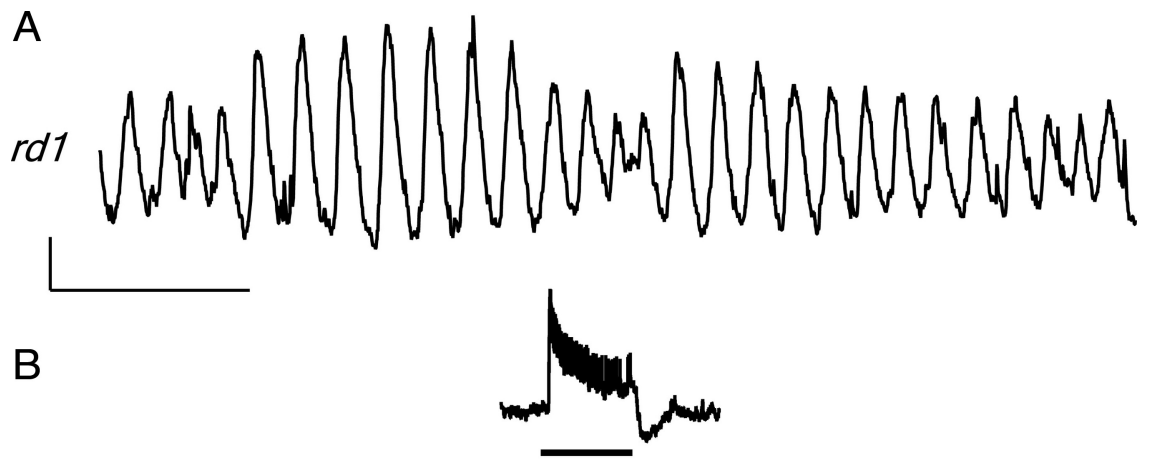

Wt
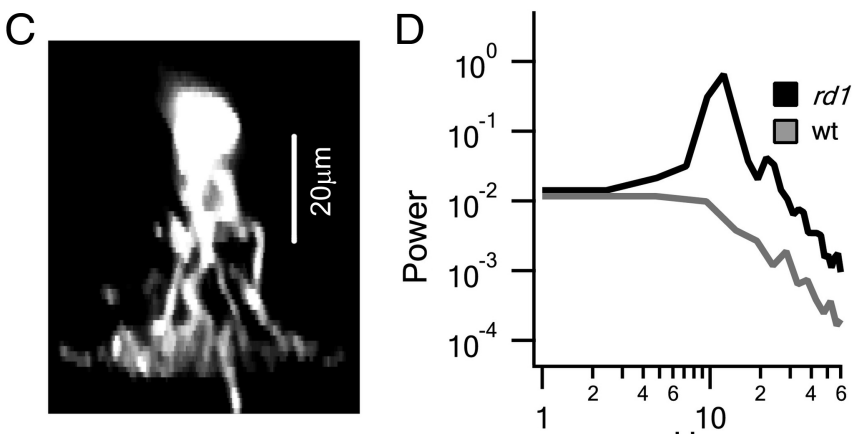

$\mathrm{Hz}$

Figure 7. Spontaneous oscillations in $r d 1$ All amacrine cells. $\boldsymbol{A}$, Spontaneous membrane oscillations in $r d 1$ but not wt $(\boldsymbol{B})$ All amacrine cells. The inset in $\boldsymbol{B}$ depicts the light response of the wt All amacrine cell. Calibration: vertical, $2 \mathrm{mV}$ for $\boldsymbol{A}$ and $\boldsymbol{B}$ and $10 \mathrm{mV}$ for inset in $\boldsymbol{B}$; horizontal, $0.5 \mathrm{~s}$ for $\boldsymbol{A}$ and $\boldsymbol{B}$ and $4 \mathrm{~s}$ for inset in $\boldsymbol{B}$. C, Two-photon image stack (rotated $90^{\circ}$ ) of an Alexa Fluor 594 -filled All amacrine cell in the whole-mount $r d 1$ retina. $D$, Power spectra of the membrane potential recorded from an $r d 1$ and wt All amacrine cell are overlaid.
A
rd1 ONCBC
B
rd1 ON CBC
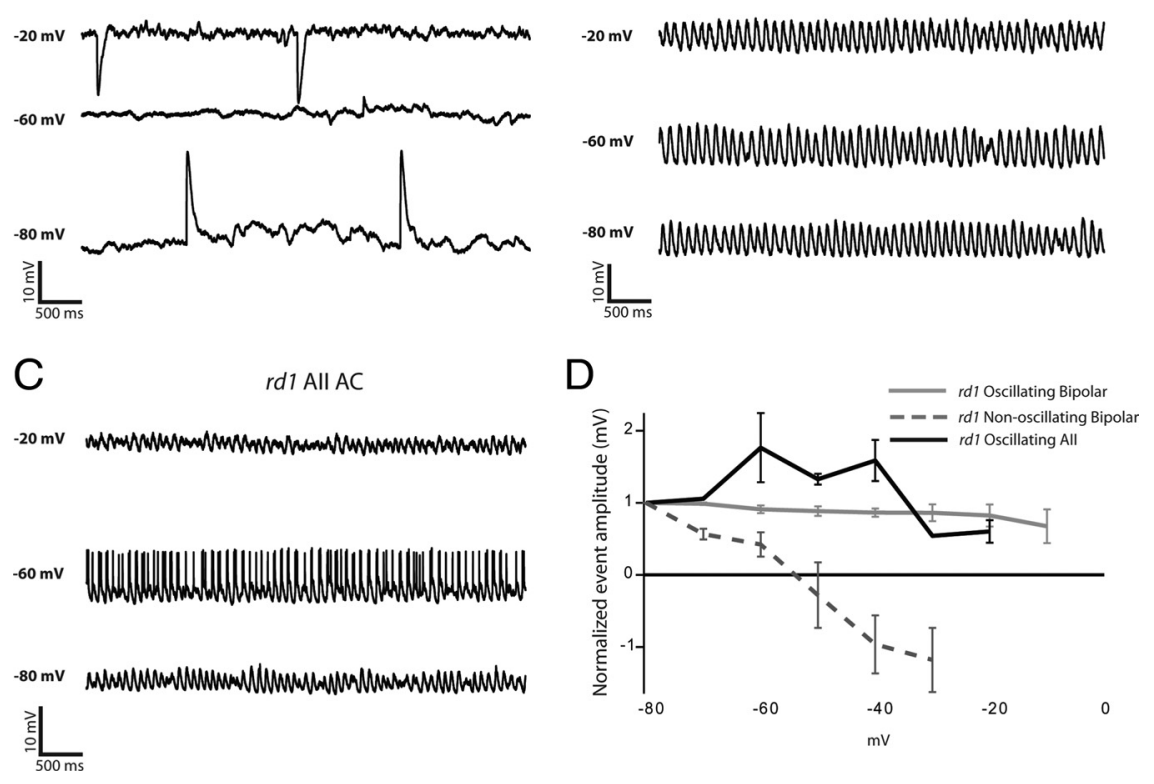

Figure 8. Voltage dependence of spontaneous oscillations in $r d 1$ cone bipolar and All amacrine cells. $\boldsymbol{A}$, Spontaneous PSPs in $r d 1$ bipolar cells reverse near $E_{C l}$, suggesting that these events are mediated by GABA or glycine receptors. $\boldsymbol{B}$, Spontaneous oscillations in $r d 10 \mathrm{~N}$ bipolar $(\boldsymbol{B})$ and All amacrine $(\boldsymbol{C})$ cells measured at different potentials, as indicated on the left side. $\boldsymbol{D}$, The normalized peak amplitude of PSPs (dotted line; $n=4$ ) and oscillatory events measured in $r d 1$ bipolar cells (gray line; $n=14$ ) and All amacrine cells (black line; $n=3$ ) plotted as a function of membrane potential. CBC, Cone bipolar cell; AC, amacrine cell. 
A

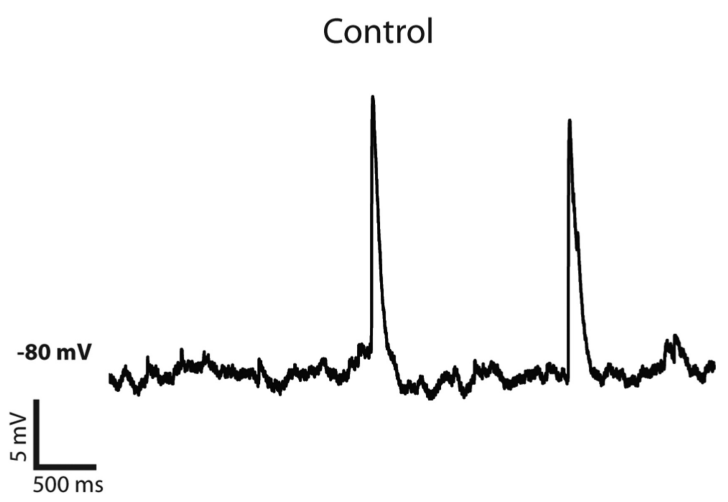

B

NBQX, AP4

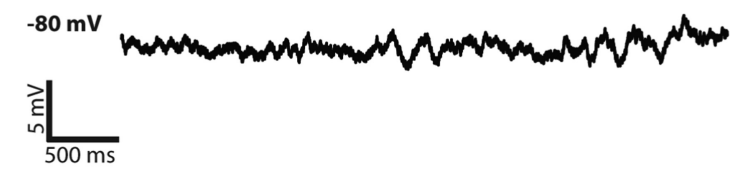

C

Control

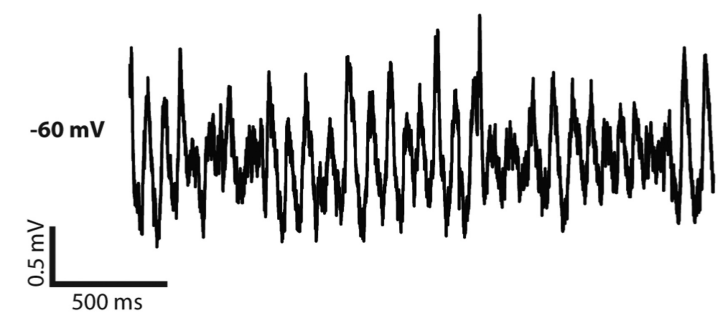

D

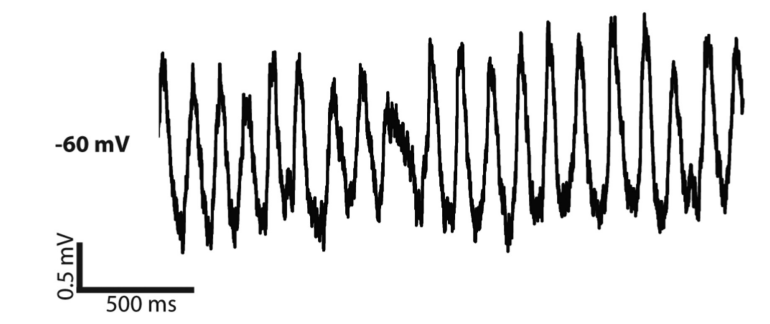

E

$$
\mathrm{Cd}^{2+}, \mathrm{Ni}^{2+}
$$

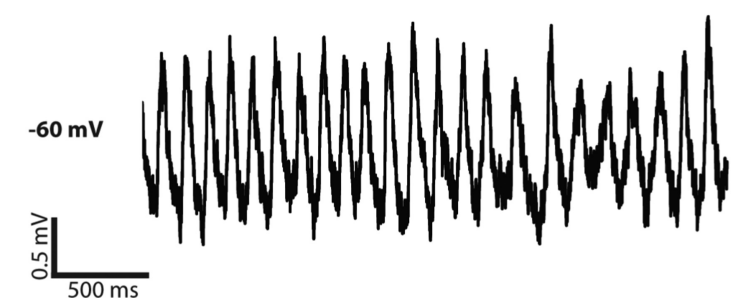

Figure 9. Spontaneous oscillations in cone bipolar cells do not rely on chemical transmission or on voltage-gate $\mathrm{Ca}^{2+}$ channels. $\boldsymbol{A}, \boldsymbol{B}$, PSPs in non-oscillating $r d 1$ bipolar cell in control Ringer's solution $(\boldsymbol{A})$ or the presence of the excitatory blockers (10 $\mu \mathrm{m} \mathrm{NBQX}$ and $20 \mu \mathrm{ML}-\mathrm{AP}-4)$ (B). C $-\boldsymbol{E}$, Spontaneous oscillations recorded in an $0 \mathrm{~N}$ cone bipolar cell in control Ringer's solution $(C$ ), in the presence of a mixture of synaptic blockers (NBQX, L-AP-4, AP-5, strychnine, and picrotoxin) (D), and in the presence of nonselective voltage-gated $\mathrm{Ca}^{2+}$ channel blockers (200 $\mu \mathrm{M}\left(\mathrm{d}^{2+}\right.$ and $\left.500 \mu \mathrm{M} \mathrm{Ni}{ }^{2+}\right)(\boldsymbol{E})$.

cinergic inhibition of the OFF bipolar cells and ganglion cells (Fig. 10). However, future pharmacological dissection of the OFF system is needed to confirm such interactions. Below we provide the evidence that leads up to the model presented in Figure 10.

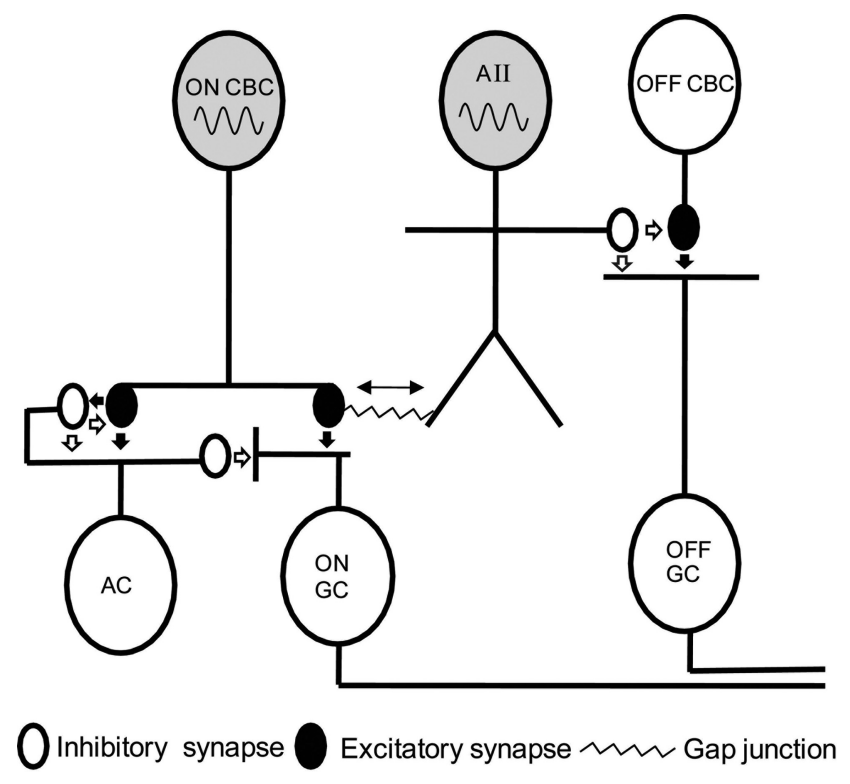

Figure 10. Retinal circuit involved in generating spontaneous activity in $r d 1$ retina. $0 N$ cone bipolar cells (ON CBCs) and electrically coupled All amacrine cells (All ACs) are intrinsically oscillatory (insensitive to synaptic blockers). ON cone bipolar cells excite both $0 \mathrm{~N}$ ganglion cells (ON GC; which use AMPA/KA and NMDA receptors) and inhibitory amacrine cells (AC; which use $A M P A / K A$ receptors). $A C s$ in turn provides reciprocal feedback inhibition to $O N C B C s$ as well as feedforward inhibition to $\mathrm{ON}$ GCS (mediated by GABA/glycine receptors). Based on comparison with wt retinal circuitry, this model has been extended to the OFF system. It is hypothesized that Alls amacrine cells drive the OFF bipolar and ganglion cells through disinhibitory mechanisms. Thus, oscillatory drive to amacrine and ganglion cells arises from intrinsic activity in the All amacrine/ON cone bipolar cell network and is strongly influenced by inhibitory amacrine cells.

First, pharmacological analysis of spontaneous synaptic inputs to ganglion cells in the $r d 1$ retina indicated that excitatory pathways could function independently of inhibitory pathways Moreover, although photoreceptor synapses may be active (Busskamp et al., 2010), oscillatory activity in the excitatory pathways did not appear to arise from the outer retina. Blocking putative inputs from remnant photoreceptors and rod ON bipolar cells (using NBQX and L-AP-4) (Kalbaugh et al., 2009) did not change the output frequency of the excitatory responses, as indicated by NMDA-receptor-mediated sEPSCs measured in ganglion cells. Thus, activity in $r d 1$ ganglion cells appears to arise at the level of the cone bipolar/AII amacrine network in the inner retina rather than in the outer retina.

Although pharmacological analysis provides some insights into the biophysical remodeling that occurs in the $r d 1$ retina, the results are difficult to interpret by themselves. Such interventions often alter the relationship between transmitter release and frequency in many parts of the CNS (Brenowitz et al., 1998; von Gersdorff and Borst, 2002; Ying et al., 2007), including the retina (Singer and Diamond, 2006; Dunn and Rieke, 2008). Indeed, when inhibitory receptors were blocked the amplitude of the sEPSCs increased and their frequency reduced. This leads to the following question: do AII/cone bipolar cells release transmitter autonomously under unperturbed conditions?

Direct recordings from bipolar and amacrine cells in a wholemount retinal preparation provide strong evidence that these cells are autonomously active. Robust membrane oscillatory potentials were observed in a variety of subtypes of $\mathrm{ON}$ cone bipolar cells and AII amacrine cells in control conditions, in the $r d 1$ but not wt retina. Such activity was of similar frequency in both the ON cone bipolar and AII amacrine cells, persisted in the presence of synaptic blockers, and was never observed in rod ON bipolar 
cells, together suggesting that oscillations arise from the electrically coupled network formed by ON cone bipolar and AII amacrine cells (as they are in wt retina) (Deans et al., 2002). In addition, cone bipolar/AII cell oscillatory potentials occurred at similar frequencies as spontaneous synaptic responses in ganglion cells, suggesting that they are a principle source of excitation in the $r d 1$ retina.

In contrast to autonomous activity in the excitatory pathway, sIPSCs measured in $r d 1$ ganglion cells were strongly reduced in the presence of glutamate receptor blockers. It is possible that the residual sIPSCs observed in the presence of glutamate receptor blockers arise from intrinsically active AII amacrine cell, because these have recently been shown to provide direct glycinergic inhibition to specific types of ganglion cells (e.g., OFF ganglion cells) (Manookin et al., 2008; Murphy and Rieke, 2008; Münch et al., 2009). However, given the large heterogeneity of amacrine cells (MacNeil and Masland, 1998), it is also possible that intrinsic activity from other unidentified types of amacrine cells contribute to the glutamate-receptor-independent activity as postulated previously (Margolis and Detwiler, 2010; Vaithianathan and Sagdullaev, 2010).

\section{Mechanisms driving autonomous activity}

Direct recordings from ON bipolar cells in $r d 1$ retina indicated that they rest at relatively hyperpolarized potentials $(\sim 50 \mathrm{mV})$, comparable with previous estimates made from recordings in the wt retina (Berntson et al., 2003; Cangiano et al., 2007). This finding was difficult to predict because photoreceptors that usually keep these cells in a hyperpolarized state (through a signinverting action mediated by mGluR6 receptors) are lost during $\mathrm{RD}$. A negative resting potential in ON bipolar cells indicates that the mGluR6 receptor cascade is either downregulated (Strettoi and Pignatelli, 2000; Puthussery and Taylor, 2010) (but see Barhoum et al., 2008) or desensitized (Awatramani and Slaughter, 2000; Berntson et al., 2004). These data are also consistent with chemical labeling studies that suggest permanent closure of the mGluR6-gated cationic channel (Marc et al., 2003). Regardless of the precise state of the mGluR6 cascade, our findings directly demonstrate that tonic depolarization of the ON bipolar cells is not the root cause of sustained activity in downstream pathways.

In wt retina, the functional coupling between voltage-gated $\mathrm{Ca}^{2+}$ channels and $\mathrm{Ca}^{2+}$-dependent $\mathrm{K}^{+}$channels are known to control the dynamic membrane properties of bipolar cells (Burrone and Lagnado, 1997; Ma and Pan, 2003; Palmer, 2006). Thus, it was surprising to find that oscillatory activity in the cone bipolar cells in the $r d 1$ retina were resistant to blockade of voltagegated $\mathrm{Ca}^{2+}$ channels by nonselective channel blockers $\mathrm{Cd}^{2+}$ and $\mathrm{Ni}^{2+}$. However, because our results suggest a strong coupling between cone bipolar and AII amacrine cells, regenerative $\mathrm{Na}^{+}$ currents in the AII amacrine cells could play an important role in endowing bipolar cells with an oscillatory potential. Future studies will determine the precise biophysical mechanisms underlying hyperactivity in the $r d 1$ retina and whether oscillations are driven by degeneration-induced modifications of the AII amacrine cells, cone bipolar cells, or both.

In other parts of the CNS, inherent properties of electrically coupled networks generate oscillations (Loewenstein et al., 2001). In wt retina, electrical coupling is an integral part of the rod pathway (Deans et al., 2002). In addition, both bipolar (Zhang and Wu, 2009; Arai et al., 2010) and AII amacrine (Veruki and Hartveit, 2002) cells may also couple to each other. Three lines of evidence suggest that bipolar cells and/or AII amacrine cells in the $r d 1$ retina form electrically coupled networks. First, oscillatory activity in both AII amacrine cells and ON bipolar cells was weakly dependent on the somatic potential. Second, in these cells types, oscillations were resistant to blockers of chemical transmission. Finally, to directly test whether electrical coupling is required for the generation of oscillatory activity, we examined the effects of meclofenamic acid (MFA), which relatively specifically blocks gap junctions including those in AII amacrine cells (Manookin et al., 2008), on spontaneous activity in ganglion cells. In contrast to the slow blocking actions of MFA on gap junctions, which occurs over a time period of 20-40 min (Veruki and Hartveit, 2009), we found that $200 \mu \mathrm{M}$ MFA rapidly suppressed spontaneous activity in ganglion cells (within 15-20 min of application) (data not shown). These preliminary results indeed suggest a critical role for gap junctions in mediating oscillations. However, it is not clear if the effects of MFA on ganglion cell activity arises from blockade of gap junctions or from secondary anticonvulsant actions (Lee and Wang, 1999, Peretz et al., 2005). The evaluation of activity in transgenic $r d 1$ mouse lines, in which specific connexins are selectively knocked out, will reveal the importance of gap junctions in mediating oscillatory activity.

Why electrically coupled networks in the $r d 1$ but not in the wt retina are more active is not completely clear. In wt retina, blockade of photoreceptor and inhibitory inputs lead to significant levels of oscillatory activity in ganglion cells. These results suggest that oscillatory mechanisms exist in the healthy retina but are not as robust as in the $r d 1$ retina. The biophysical changes that account for a more pronounced oscillatory potential in $r d 1$ retina remain to be elucidated.

\section{Implications of network hyperactivity on visual function}

Efficient retinal coding requires visually evoked signals to have a high signal-to-noise ratio. In response to reduced sensory inputs during degeneration, homeostatic mechanisms appear to increase synaptic gain at the expense of increasing noise levels. It could be argued that, under suboptimal conditions, increased noise could permit weak signals to reach spiking threshold and paradoxically increase the signal-to-noise ratio (Patel and Kosko, 2005). Moreover, membrane oscillations could favor the transfer of a specific bandwidth of information to higher visual centers. Nonetheless, when artificial methods are applied with prosthetic devices and signals are suprathreshold, increased background noise would likely degrade quality of the restored image (Powers et al., 1995; Hallum et al., 2006). Our current study provides direct evidence that a principal component of the spontaneous activity in the $r d 1$ retina arises from intrinsic activity in networks of ON cone bipolar and AII amacrine cells.

\section{References}

Acland GM, Aguirre GD, Ray J, Zhang Q, Aleman TS, Cideciyan AV, PearceKelling SE, Anand V, Zeng Y, Maguire AM, Jacobson SG, Hauswirth WW, Bennett J (2001) Gene therapy restores vision in a canine model of childhood blindness. Nat Genet 28:92-95.

Arai I, Tanaka M, Tachibana M (2010) Active roles of electrically coupled bipolar cell network in the adult retina. J Neurosci 30:9260-9270.

Awatramani GB, Slaughter MM (2000) Origin of transient and sustained responses in ganglion cells of the retina. J Neurosci 20:7087-7095.

Awatramani GB, Slaughter MM (2001) Intensity-dependent, rapid activation of presynaptic metabotropic glutamate receptors at a central synapse. J Neurosci 21:741-749.

Awatramani GB, Boyd JD, Delaney KR, Murphy TH (2007) Effective release rates at single rat Schaffer collateral-CAI synapses during sustained thetaburst activity revealed by optical imaging. J Physiol 582:583-595.

Barhoum R, Martínez-Navarrete G, Corrochano S, Germain F, FernandezSanchez L, de la Rosa EJ, de la Villa P, Cuenca N (2008) Functional and structural modifications during retinal degeneration in the $\mathrm{rd} 10$ mouse. Neuroscience 155:698-713. 
Berntson A, Taylor WR, Morgans CW (2003) Molecular identity, synaptic localization, and physiology of calcium channels in retinal bipolar cells. J Neurosci Res 71:146-151.

Berntson A, Smith RG, Taylor WR (2004) Postsynaptic calcium feedback between rods and rod bipolar cells in the mouse retina. Vis Neurosci 21:913-924.

Bi A, Cui J, Ma YP, Olshevskaya E, Pu M, Dizhoor AM, Pan ZH (2006) Ectopic expression of a microbial-type rhodopsin restores visual responses in mice with photoreceptor degeneration. Neuron 50:23-33.

Borowska JT, Trenholm S, Awatramani GB (2010) Intrinsic mechanisms in bipolar cells drive spontaneous network activity during retinal degeneration. ARVO Meet Abstr 46:2486.

Brenowitz S, David J, Trussell L (1998) Enhancement of synaptic efficacy by presynaptic GABA(B) receptors. Neuron 20:135-141.

Burrone J, Lagnado L (1997) Electrical resonance and $\mathrm{Ca}^{2+}$ influx in the synaptic terminal of depolarizing bipolar cells from the goldfish retina. J Physiol 505:571-584.

Busskamp V, Duebel J, Balya D, Fradot M, Viney TJ, Siegert S, Groner AC, Cabuy E, Forster V, Seeliger M, Biel M, Humphries P, Paques M, Mohand-Said S, Trono D, Deisseroth K, Sahel JA, Picaud S, Roska B (2010) Genetic reactivation of cone photoreceptors restores visual responses in retinitis pigmentosa. Science 329:413-417.

Cangiano L, Gargini C, Della Santina L, Demontis GC, Cervetto L (2007) High-pass filtering of input signals by the Ih current in a non-spiking neuron, the retinal rod bipolar cell. PLoS One 2:e1327.

Carter-Dawson LD, LaVail MM, Sidman RL (1978) Differential effect of the rd mutation on rods and cones in the mouse retina. Invest Ophthalmol Vis Sci 17:489-498.

Chen M, Weng S, Deng Q, Xu Z, He S (2009) Physiological properties of direction-selective ganglion cells in early postnatal and adult mouse retina. J Physiol 587:819-828.

Deans MR, Volgyi B, Goodenough DA, Bloomfield SA, Paul DL (2002) Connexin36 is essential for transmission of rod-mediated visual signals in the mammalian retina. Neuron 36:703-712.

Diamond JS, Copenhagen DR (1993) The contribution of NMDA and nonNMDA receptors to the light-evoked input-output characteristics of retinal ganglion cells. Neuron 11:725-738.

Dunn FA, Rieke F (2008) Single-photon absorptions evoke synaptic depression in the retina to extend the operational range of rod vision. Neuron 57:894-904.

Ghosh KK, Bujan S, Haverkamp S, Feigenspan A, Wässle H (2004) Types of bipolar cells in the mouse retina. J Comp Neurol 469:70-82.

Hallum LE, Chen SC, Cloherty SL, Lovell NH (2006) Psychophysics of prosthetic vision. II. stochastic sampling, the phosphene image, and noise. Conf Proc IEEE Eng Med Biol Soc 1:1634-1637.

Hoelter SM, Dalke C, Kallnik M, Becker L, Horsch M, Schrewe A, Favor J, Klopstock T, Beckers J, Ivandic B, Gailus-Durner V, Fuchs H, Hrabé de Angelis M, Graw J, Wurst W (2008) "Sighted C3H" mice: a tool for analysing the influence of vision on mouse behaviour? Front Biosci 13:5810-5823.

$\mathrm{Hu} \mathrm{HJ}$, Pan ZH (2002) Differential expression of $\mathrm{K}^{+}$currents in mammalian retinal bipolar cells. Vis Neurosci 19:163-173.

Ivanova E, Müller F (2006) Retinal bipolar cell types differ in their inventory of ion channels. Vis Neurosci 23:143-154.

Jahr CE, Stevens CF (1990) Voltage dependence of NMDA-activated macroscopic conductances predicted by single-channel kinetics. J Neurosci 10:3178-3182.

Kalbaugh TL, Zhang J, Diamond JS (2009) Coagonist release modulates NMDA receptor subtype contributions at synaptic inputs to retinal ganglion cells. J Neurosci 29:1469-1479.

Lagali PS, Balya D, Awatramani GB, Münch TA, Kim DS, Busskamp V, Cepko CL, Roska B (2008) Light-activated channels targeted to ON bipolar cells restore visual function in retinal degeneration. Nat Neurosci 11:667-675.

Lee YT, Wang Q (1999) Inhibition of hKv2.1, a major human neuronal voltage-gated $\mathrm{K}^{+}$channel, by meclofenamic acid. Eur J Pharmacol 378:349-356.

Lin B, Koizumi A, Tanaka N, Panda S, Masland RH (2008) Restoration of visual function in retinal degeneration mice by ectopic expression of melanopsin. Proc Natl Acad Sci U S A 105:16009-16014.

Lin B, Masland RH, Strettoi E (2009) Remodeling of cone photoreceptor cells after rod degeneration in rd mice. Exp Eye Res 88:589-599.

Loewenstein Y, Yarom Y, Sompolinsky H (2001) The generation of oscilla- tions in networks of electrically coupled cells. Proc Natl Acad Sci U S A 98:8095-8100.

Ma YP, Pan ZH (2003) Spontaneous regenerative activity in mammalian retinal bipolar cells: roles of multiple subtypes of voltage-dependent $\mathrm{Ca}^{2+}$ channels. Vis Neurosci 20:131-139.

Ma YP, Cui J, Hu HJ, Pan ZH (2003) Mammalian retinal bipolar cells express inwardly rectifying $\mathrm{K}^{+}$currents (IKir) with a different distribution than that of Ih. J Neurophysiol 90:3479-3489.

MacLaren RE, Pearson RA, MacNeil A, Douglas RH, Salt TE, Akimoto M, Swaroop A, Sowden JC, Ali RR (2006) Retinal repair by transplantation of photoreceptor precursors. Nature 444:203-207.

MacNeil MA, Masland RH (1998) Extreme diversity among amacrine cells: implications for function. Neuron 20:971-982.

Manookin MB, Beaudoin DL, Ernst ZR, Flagel LJ, Demb JB (2008) Disinhibition combines with excitation to extend the operating range of the OFF visual pathway in daylight. J Neurosci 28:4136-4150.

Manookin MB, Weick M, Stafford BK, Demb JB (2010) NMDA receptor contributions to visual contrast coding. Neuron 67:280-293.

Marc RE, Jones BW, Watt CB, Strettoi E (2003) Neural remodeling in retinal degeneration. Prog Retin Eye Res 22:607-655.

Marc RE, Jones BW, Anderson JR, Kinard K, Marshak DW, Wilson JH, Wensel T, Lucas RJ (2007) Neural reprogramming in retinal degeneration. Invest Ophthalmol Vis Sci 48:3364-3371.

Margolis DJ, Detwiler PB (2011) Cellular origin of spontaneous ganglion cell spike activity in animal models of retinitis pigmentosa. J Ophthalmol pii:507037.

Margolis DJ, Newkirk G, Euler T, Detwiler PB (2008) Functional stability of retinal ganglion cells after degeneration-induced changes in synaptic input. J Neurosci 28:6526-6536.

Mazzoni F, Novelli E, Strettoi E (2008) Retinal ganglion cells survive and maintain normal dendritic morphology in a mouse model of inherited photoreceptor degeneration. J Neurosci 28:14282-14292.

Müller F, Scholten A, Ivanova E, Haverkamp S, Kremmer E, Kaupp UB (2003) HCN channels are expressed differentially in retinal bipolar cells and concentrated at synaptic terminals. Eur J Neurosci 17:2084-2096.

Münch TA, da Silveira RA, Siegert S, Viney TJ, Awatramani GB, Roska B (2009) Approach sensitivity in the retina processed by a multifunctional neural circuit. Nat Neurosci 12:1308-1316.

Murphy GJ, Rieke F (2008) Signals and noise in an inhibitory interneuron diverge to control activity in nearby retinal ganglion cells. Nat Neurosci 11:318-326.

Oesch N, Euler T, Taylor WR (2005) Direction-selective dendritic action potentials in rabbit retina. Neuron 47:739-750.

Palmer MJ (2006) Modulation of $\mathrm{Ca}^{2+}$-activated $\mathrm{K}^{+}$currents and $\mathrm{Ca}^{2+}$ dependent action potentials by exocytosis in goldfish bipolar cell terminals. J Physiol 572:747-762.

Patel A, Kosko B (2005) Stochastic resonance in noisy spiking retinal and sensory neuron models. Neural Netw 18:467-478.

Peretz A, Degani N, Nachman R, Uziyel Y, Gibor G, Shabat D, Attali B (2005) Meclofenamic acid and diclofenac, novel templates of KCNQ2/Q3 potassium channel openers, depress cortial neuron activity and exhibit anticonvulsant properties. Mol Pharmacol 67:1053-1066.

Petit-Jacques J, Völgyi B, Rudy B, Bloomfield S (2005) Spontaneous oscillatory activity of starburst amacrine cells in the mouse retina. J Neurophysiol 94:1770-1780.

Powers NL, Salvi RJ, Wang J, Spongr V, Qiu CX (1995) Elevation of auditory thresholds by spontaneous cochlear oscillations. Nature 375:585-587.

Puthussery T, Taylor WR (2010) Functional changes in inner retinal neurons in animal models of photoreceptor degeneration. Adv Exp Med Biol 664:525-532.

Quraishi S, Gayet J, Morgans CW, Duvoisin RM (2007) Distribution of group-III metabotropic glutamate receptors in the retina. J Comp Neurol 501:931-943.

Sagdullaev BT, McCall MA, Lukasiewicz PD (2006) Presynaptic inhibition modulates spillover, creating distinct dynamic response ranges of sensory output. Neuron 50:923-935.

Singer JH, Diamond JS (2006) Vesicle depletion and synaptic depression at a mammalian ribbon synapse. J Neurophysiol 95:3191-3198.

Slaughter MM, Miller RF (1981) 2-amino-4-phosphonobutyric acid: a new pharmacological tool for retina research. Science 211:182-185.

Solessio E, Vigh J, Cuenca N, Rapp K, Lasater EM (2002) Membrane prop- 
erties of an unusual intrinsically oscillating, wide-field teleost retinal amacrine cell. J Physiol 544:831-847.

Stasheff SF (2008) Emergence of sustained spontaneous hyperactivity and temporary preservation of OFF responses in ganglion cells of the retinal degeneration $(r d 1)$ mouse. J Neurophysiol 99:1408-1421.

Stasheff SF, Andrews MP (2010) A subpopulation of retinal ganglion cells sustains spontaneous hyperactivity through non-synaptic mechanisms in mice with retinal degeneration. Abstract (5798) presented at the annual meeting of the Association for Research in Vision and Ophthalmology (ARVO), Fort Lauderdale, FL, May.

Strettoi E, Pignatelli V (2000) Modifications of retinal neurons in a mouse model of retinitis pigmentosa. Proc Natl Acad Sci U S A 97:11020-11025.

Strettoi E, Porciatti V, Falsini B, Pignatelli V, Rossi C (2002) Morphological and functional abnormalities in the inner retina of the $\mathrm{rd} / \mathrm{rd}$ mouse. J Neurosci 22:5492-5504.

Tropepe V, Coles BL, Chiasson BJ, Horsford DJ, Elia AJ, McInnes RR, van der Kooy D (2000) Retinal stem cells in the adult mammalian eye. Science 287:2032-2036

Vaithianathan T, Sagdullaev BT (2010) Functional remodeling of inner retinal synaptic transmission during photoreceptor degeneration. ARVO Meet Abstr 51:2483.

Varela C, Igartua I, De la Rosa EJ, De la Villa P (2003) Functional modifications in rod bipolar cells in a mouse model of retinitis pigmentosa. Vision Res 43:879-885.

Veruki ML, Hartveit E (2002) AII (Rod) amacrine cells form a network of electrically coupled interneurons in the mammalian retina. Neuron 33:935-946.

Veruki ML, Hartveit E (2009) Meclofenamic acid blocks electrical synapses of retinal AII amacrine and on-cone bipolar cells. J Neurophysiol 101: 2339-2347.

Vigh J, Solessio E, Morgans CW, Lasater EM (2003) Ionic mechanisms mediating oscillatory membrane potentials in wide-field retinal amacrine cells. J Neurophysiol 90:431-443.

von Gersdorff H, Borst JG (2002) Short-term plasticity at the calyx of held. Nat Rev Neurosci 3:53-64.

Wässle H, Puller C, Müller F, Haverkamp S (2009) Cone contacts, mosaics, and territories of bipolar cells in the mouse retina. J Neurosci 29:106-117.

Weiland JD, Liu W, Humayun MS (2005) Retinal prosthesis. Annu Rev Biomed Eng 7:361-401.

Ye JH, Goo YS (2007) The slow wave component of retinal activity in $\mathrm{rd} / \mathrm{rd}$ mice recorded with a multi-electrode array. Physiol Meas 28:1079-1088.

Ying SW, Jia F, Abbas SY, Hofmann F, Ludwig A, Goldstein PA (2007) Dendritic $\mathrm{HCN} 2$ channels constrain glutamate-driven excitability in reticular thalamic neurons. J Neurosci 27:8719-8732.

Zeck G, Menzler J (2010) Network oscillations in rod degenerated ( $r d 1)$ retina. ARVO Meet Abstr 46:5799.

Zhang AJ, Wu SM (2009) Receptive fields of retinal bipolar cells are mediated by heterogeneous synaptic circuitry. J Neurosci 29:789-797. 